\title{
Title: Interventions to Support Autonomy, Competence, and Relatedness Needs in Organizations: A Systematic Review with Recommendations for Research and Practice
}

Short title: REVIEW OF BASIC NEED SUPPORT INTERVENTIONS

Gavin R. Slemp*1, Mark A. Lee ${ }^{2}$, and Lara H. Mossman ${ }^{1,3}$

${ }^{1}$ The University of Melbourne

Centre for Positive Psychology

Melbourne Graduate School of Education

${ }^{2}$ RMIT University

School of Health and Biomedical Sciences

${ }^{3}$ La Trobe University

School of Psychology and Public Health

*Corresponding author information:

Gavin R. Slemp

The University of Melbourne

Level 2, 100 Leicester Street

Parkville, 3010, ph. +61 39035 4877, (e-mail: gavin.slemp@unimelb.edu.au).

\begin{abstract}
:
Organizational research underpinned by self-determination theory (SDT) has grown substantially over the past decade. However, the effectiveness of interventions designed to promote support for basic psychological needs in organizations remains ill documented. We thus report the results of a qualitative systematic review and synthesis of SDT-informed studies of interventions to cultivate autonomy, competence, and relatedness needs, and in turn, autonomous motivation in organizational contexts. Studies were included in the review if they evaluated the effect of interventions to develop autonomy-, competence-, or relatedness-supportive work climates or leader behaviors. A systematic search yielded ten eligible field studies for inclusion: three randomized-controlled trials and seven non-randomized intervention studies (combined $N=2,337$ ). Seven studies yielded mostly favorable effects, two yielded mixed effects, and one study showed no evidence of change post-intervention. Substantial heterogeneity in intervention format and delivery existed across studies. Studies pointed towards possible moderators of effectiveness. Interventions were more effective at spawning change at the proximal (leader) level than at
\end{abstract}


the distal (subordinate) level, though few studies tracked employees over-time to comprehensively evaluate long-term transfer. Bias assessments showed that risk of bias was moderate or high across studies. We discuss overall implications of the review and suggest several recommendations for future intervention research and practice.

\section{Keywords:}

self-determination theory, autonomy support, competence support, relatedness support, basic psychological needs, intervention, systematic review, leadership

\section{Data availability statement:}

Data sharing is not applicable to this article as no new data were created or analyzed in this study.

(Templates available at: https://authorservices.wiley.com/author-resources/Journal-Authors/openaccess/data-sharing-citation/data-sharing-policy.html)

\section{Acknowledgements:}

This project was supported by an internal research development award offered by the Melbourne Graduate School of Education, The University of Melbourne. 


\section{Practitioner points:}

- Interventions to help leaders to support subordinates' basic psychological needs are effective in creating change in leader behavior

- Intervention effects for subordinate outcomes are smaller and may take time to materialize

- Interventions tend to be more effective if they are aligned with organizational strategic needs, proactively consider unique work contexts, are endorsed by senior levels of management, and give preference to pedagogy that aligns with basic needs 


\section{Interventions to Support Autonomy, Competence, and Relatedness Needs in Organizations: A Systematic Review with Recommendations for Research and Practice}

A motivated, productive, and flourishing workforce is vital to organizational success, the pursuit of which is a central aim of organizational leadership (Pinder, 2014). Consequently, organizations are continually seeking ways to enhance their employees' well-being, motivation, and performance. Among the collective repertoire of tools is a diverse range of occupational health interventions aimed to advance employee welfare, with recent decades realizing an emergent interest in interventions underpinned by "positive” scholarship (Bakker \& Schaufeli, 2008; Bakker \& van Woerkom, 2018). Self-determination theory (SDT; Ryan \& Deci, 2000, 2017)—a macro-theory of motivation that emphasizes the conditions that facilitate self-motivation and optimal psychological development — has provided an influential perspective upon which to design these interventions (Deci et al., 2017; Gagné \& Deci, 2005). A distinguishing feature is a focus on nurturing employee psychological needs, and in turn, optimal forms of work motivation.

SDT suggests that employees achieve optimal functioning to the extent that they are autonomously motivated - a state where they self-endorse and volitionally engage in their work because they find it inherently enjoyable or valuable. A precondition to autonomous motivation is thought to be the satisfaction of psychological needs for autonomy, competence, and relatedness (Deci et al., 2017; Slemp et al., 2018, 2020), the cultivation of which typically forms the basis of SDT-informed interventions to improve employee functioning. Despite a growing literature on SDT in the workplace (Van den Broeck et al., 2016), there currently has been no attempt to synthesize prior insights from intervention studies designed to engender support for the three needs in the workplace. A systematic review is warranted because it will help to consolidate fragmented insights into a more unified knowledgebase, serving practitioners in the design of future interventions. A systematic review will also identify gaps in knowledge to advance future research. We thereby report the results of a systematic review and qualitative synthesis of intervention studies designed to examine supports for employee basic needs and autonomous motivation in organizations. For these purposes, our review focuses on SDT-informed intervention field studies that contain strategies to 
promote support for autonomy, competence, and relatedness needs in organizations, which can be targeted at leadership, employees, or work design (Beehr, 2019).

\section{Self-Determination Theory in Organizations}

SDT is a general theory of human motivation that assumes people agentic beings with evolved tendencies toward mastering challenges, pursuing growth, and integrating new experiences with the self (Ryan \& Deci, 2017). The theory specifies that these tendencies manifest when people fulfill their basic psychological needs for autonomy, competence, and relatedness (Deci \& Ryan, 2000; Van den Broeck et al., 2010). Autonomy requires the inner endorsement of behavior, such that people experience a sense of ownership over their actions (Ryan \& Connell, 1989). Competence requires overcoming challenges and developing a sense of mastery (Deci \& Ryan, 2000).

Relatedness involves a sense of mutual connection, belonging, and feeling reciprocally cared for by others (Baumeister \& Leary, 1995).

SDT suggests the three needs provide an important precursor for employee motivation, wellbeing, and performance (Deci et al. 2017; Slemp et al., 2018; Van Den Broeck et al., 2016) and thus, the antecedents to need satisfaction have provided a prominent avenue for organizational research. Because a key postulate of SDT is that tendencies towards growth are conditional upon the socialcontext (Deci \& Ryan, 1987; Mageau \& Vallerand, 2003), much of this research has targeted the behaviors displayed from important others that are thought to support employee autonomy, competence, and relatedness (Deci et al., 2001; Deci \& Ryan, 2000; Ryan \& Deci, 2017; Su \& Reeve, 2011). In the workplace, autonomy support refers to actions that foster more exploratory, discretionary work behaviors: offering opportunities for choice and input, encouraging self-initiation, and avoiding the use of external controls such as rewards or sanctions to prompt specific job behaviors (Deci et al., 1989; Slemp et al., 2018). Competence support involves actions that foster employee efficacy or mastery: sharing knowledge, providing guidance and structure, affording informational feedback, and establishing realistic yet challenging expectations (Bernsten \& Kristiansen, 2019; Ryan \& Deci, 2017). Relatedness support refers to behaviors that demonstrate ongoing and authentic interest, care, and companionship amongst employees: active listening, 
perspective taking, mentoring, and opportunities to develop relations with others (Van den Broeck et al., 2016).

Basic need supports for autonomy, competence, and relatedness and, in turn, basic need satisfaction are seen essential precursors to autonomous (self-determined) employee motivation (Deci et al., 2017; Ryan \& Deci, 2017). While other motivation-based theories focus on the intensity of motivation, SDT makes a quality distinction, central of which is that between autonomous and controlled motivation (Gagné \& Deci, 2005; See Figure 1 in Ryan \& Deci, 2000). Autonomous motivation encompasses behaviors that emanate from within the self, requiring a sense of volition and choice. Autonomously motivated behaviors can be due to pure enjoyment (intrinsic motivation), identity congruence (integrated regulation) or value placed on the activity (identified regulation) (Gagné \& Deci, 2005). In contrast, controlled motivation involves behaviors performed due to a perceived pressure to do so (Deci et al., 2017). It generally requires a sense of obligation to perform an action and can be due to internal pressure (e.g., guilt) placed on the self (introjected regulation), or fully external pressure due to reward or punishment contingencies (external regulation). An important part of this motivational framework is internalization, suggesting that if the social context is supportive of basic needs, people begin to internalize the value of their behavior, transforming controlled motivations into more autonomous forms motivation (Deci et al., 1994; Ryan, 1995).

A vast body of research suggests that basic need satisfaction and, in turn, autonomous motivation is associated with desirable work outcomes, including lower burnout and distress (Fernet et al., 2012; Van den Broeck et al., 2008), organizational commitment (Chong et al., 2020) work engagement (Deci et al., 2001) as well as performance, creativity, and proactive behaviors such as job crafting (Bindl et al., 2019; Slemp et al., 2015; Slemp, 2017). Thus, need supports have formed the underpinning for organizational interventions designed to engender these positive work outcomes. Interest in organizational interventions began as early as Deci et al. (1989), who observed that when subordinates perceived their leaders as more autonomy supportive after leadership training, they showed elevated satisfaction with supervision, as well as job satisfaction and trust in senior leadership. Since then, vast numbers of observational studies have yielded cross-sectional and 
longitudinal evidence supporting the benefits of cultivating basic needs (see Van den Broeck et al., 2016; Slemp et al., 2018 for reviews), but it was only relatively recently when intervention studies again began to emerge.

While the intervention literature is still in its infancy, recent studies show promising yet inconsistent findings. For example, Hardré and Reeve (2009) conducted an RCT and found that after just 2-hours of training, leaders demonstrated greater autonomy supportiveness and, 5-weeks later, subordinates showed less controlled motivation and greater work engagement. More recent studies, however, have yielded mixed results. Tafvelin et al. (2019), for example, conducted a large quasiexperimental trial also of leadership training designed to promote support for the basic needs and did not find significant changes in leader behavior or subordinate outcomes. Forner (2019) and Yong et al. (2019b) conducted similar leadership training studies and showed beneficial effects emerged for some measures, or across some assessment periods, but benefits were far from universal. Yet other studies that utilize different types of training, such as that delivered to employees directly (e.g., Jungert et al., 2018; Pedersen et al., 2018, 2019) have shown beneficial effects. Thus, there is a need to determine what the literature overall suggests about the effectiveness of interventions designed to promote support for employee basic needs. A systematic review will help address this need and allows for stronger inferences about effectiveness than single studies alone (Gough et al., 2017). Systematic review will also help to uncover possible factors affecting the effectiveness of interventions, one possibility of which might be the intervention evaluation process, an issue to which we turn next.

\section{Evaluating Intervention Effectiveness}

According to Kirkpatrick (1959), when evaluating training interventions, effectiveness can be evaluated using four categories of outcomes that reflect the sequential order by which they are impacted following the intervention. Reactions are the most proximal outcome category and reflect the attitudinal component of effectiveness, such as perceived satisfaction with leadership training. Next is learning, which reflects sustained changes produced in participant knowledge, skills, affect, motivations, or job attitudes. Transfer reflects the extent to which participants implement the skills or 
abilities that were acquired in the learning stage. Finally, the most distal outcome category is results, which refers to the intervention's effect on the organization's ability to achieve its objectives (e.g., costs, profits, turnover). In their meta-analysis of leadership interventions, Lacerenza et al. (2017) further differentiate results into organizational results (e.g., profit, costs) and subordinate results (e.g., subordinate job attitudes or behaviors). Because need-supportive training interventions are typically designed to engender the requisite interpersonal conditions for need satisfaction and autonomous motivation to emerge (Deci et al., 1989; Ryan \& Deci, 2017), interventions often target change efforts at a proximal level (e.g., leader behavior), which is designed to trigger more distal "trickle-down" benefits in subordinates, peers, or the organization. Studies therefore generally need to employ multi-level sampling strategies that encompass proximal (e.g., leaders) and distal (e.g., subordinate) participants to detect both types of effects (not to be confused with nested data structures or multi-level modeling).

Insert Figure 1 about here

Figure 1 shows such a process reflected in a typical research study in this literature, which maps the general theoretical process by which need-supportive interventions are thought to yield autonomous motivation and positive outcomes in organizations. In the Figure, we overlay this process onto Kirkpatrick (1959) evaluation criteria and study sampling to illustrate how these effects are captured in intervention research. The figure starts with the structured delivery of needsupportive interventions to promote autonomy-, competence-, and relatedness-supportive behaviors or procedures in organizations. Assuming the intervention is effective, proximal changes will be observed in the intervention participants, such as a positive attitude towards the intervention, as well as learning and skill-acquisition relevant to supporting basic needs. These changes are considered proximal because they are generally the first to emerge post-intervention. Example content that could invoke these effects are an exploration of on-the-job approaches to support autonomy (e.g., offering choice within limits), competence (e.g., providing feedback), and relatedness (e.g., facilitating connections) in their workplace. After the intervention, to the extent that participants utilize these 
learnings and skills (i.e., they transfer these into on-the-job behaviors, depicted by the dashed vertical line in the center of Figure 1), subordinates will perceive an increase in autonomy, competence, and relatedness supportive behaviors, which triggers more distal motivational, wellness, and behavioral benefits. These benefits are considered distal because they do not occur in participants who receive the intervention directly, but rather in the distal sample, involving people to whom training participants are connected (e.g., subordinates, peers). Hence, they are contingent on the successful transfer of intervention learnings to on-the-job behaviors in training participants.

On the right-hand side of Figure 1 we display the theoretical process by which distal benefits are thought to emerge in employees post intervention. This process is based on that proposed by Deci et al. (2017), whereby social-contextual supports for autonomy, competence, and relatedness needs enable employees to more freely and competently engage in behaviors that support their basic needs. Hence, need supports are viewed as social-contextual motivational antecedents to employee need satisfaction. In turn, because the satisfaction of employee basic needs tends to trigger enjoyment and value for the work itself, need satisfaction is understood to be central for fuller internalization and, in turn, autonomous motivation (Deci et al., 2001, 2017). Thus, SDT positions need satisfaction as an antecedent, rather than an outcome, of autonomous motivation (Deci et al., 2017; Gagné, 2003; Ryan $\&$ Deci, 2017). Finally, to the extent that motivation for work is autonomous, employees are more likely to display enhanced functioning in the workplace (e.g., Slemp et al., 2020a). This can manifest psychologically, such as in increased work engagement, job satisfaction, or well-being (Van den Broeck et al., 2016). It can also manifest behaviorally through prosocial or proactive behaviors, or work performance. These changes would be reflected in the results criteria of the Kirkpatrick (1959) model - the most distal level of change to occur from basic need support interventions.

While studies need to include multi-level sampling for effectiveness to be comprehensively evaluated at Kirkpatrick's results level, not all studies include proximal and distal samples to achieve this aim. This is important because distal effects in subordinates, peers, or the organization, are often contingent on the training recipients transferring their learnings into on-the-job behaviors, which means distal effects likely take time to materialize - a delay that is unlikely to be captured in single- 
level research. Effects are also likely moderated by factors such as the frequency, duration, longevity, and quality of leader-subordinate interactions (Alinson et al., 2001; Epitropaki \& Martin, 1999), contributing to the general finding of smaller meta-analytic effect sizes for subordinate results after leadership interventions (Lacerenza et al., 2017).

While prior meta-analyses of SDT interventions in healthcare do not differentiate Kirkpatrick criteria (Gillison et al., 2019; Ntoumanis et al., 2020), we suggest this step is necessary in order to evaluate more distal effects in subordinate, organizational, or peer results. This is especially important as studies vary in design and evaluation timelines, which may impact whether they can sufficiently assess intervention effectiveness at different levels. An exhaustive systematic review of the literature with systematic coding of study characteristics is one way to examine this issue, which we explore in detail in the present review.

\section{The Present Study}

Although several studies have examined interventions to promote employee autonomous motivation in organizations via the promotion of autonomy, competence, and relatedness supportive behaviors, no attempt has yet been made to systematically locate and review the studies in this literature. Accordingly, questions pertaining to interventions effectiveness, factors that impact effectiveness, and valuable directions for future research, have not been sufficiently synthesized.

In conducting our systematic review, we had three primary aims. First, consistent with theme of the special issue, we aimed to advance literature on work motivation and positive organizational interventions (Pinder, 2014; Roberts, 2006) by presenting a systematic, qualitative synthesis of interventions designed to support employee basic needs for autonomy, competence, and relatedness, and in turn, autonomous motivation. In doing so, we extend prior reviews of this literature that have focused on non-intervention research (Deci et al., 2017; Slemp et al., 2018; Van den Broeck et al., 2016), and synthesize the impact on basic needs, motivation, behavior, and well-being outcomes. Our second aim was to explore factors that affect intervention effectiveness, which may inform practice. We thereby catalogue research design, evaluation, and training features, as well as scrutinize qualitative data reported in mixed-method studies relevant to intervention effectiveness. Our final 
aim was to identify several directions for future research for those interested in exploring interventions using an SDT approach. In doing so, we highlight what we believe to be limitations of the literature that future research could overcome, with specific recommendations.

\section{METHOD}

\section{Search Strategy and Eligibility Criteria}

We initially searched eight electronic databases for relevant records published through to June 2019, and updated the search in June 2020. Databases were PsycINFO, Web of Science, Scopus, MEDLINE, Academic Search Complete, Business Source Complete, ERIC, and ProQuest Dissertations and Theses Global. We used two sets of search terms to capture autonomy support and other need supports, as well as intervention-based studies (see our supplemental materials for our search terms). Searches were conducted by combining all words from both word sets using the Boolean operator "OR" to separate words within sets, and the "AND" operator to combine sets. This ensured any study with at least one word from each set would be captured. Truncation symbols $(*)$ were added to word stems to capture different spellings. We also snowballed the reference lists of existing relevant SDT meta-analyses (e.g., Howard et al., 2017; Gillison et al., 2019; Ntoumanis et al., 2020; Slemp et al., 2018; Van Den Broeck et al., 2016) to identify other sources.

Shown in Figure 1, these procedures led to the identification of 7,328 records, of which 6,379 were through databases and 949 from other sources. We were left with 3,470 records after duplicates were removed. Initial screening of titles and abstracts led to the exclusion of 3,097 further records due to obvious irrelevancy or failure to meet our inclusion criteria (specified below). We examined the full text of the remaining 373 records. A further 363 were removed for failing to meet our inclusion criteria. This left 10 eligible workplace intervention studies for inclusion in the systematic review. Nine of these constituted training interventions, six of which targeted leadership and three of which targeted employees directly. One study structurally embedded need supports into the organizational work design. All 10 studies focused on fostering autonomous motivation via cultivating need supports, with none targeting the internalization process directly. The final step in 
the process was to snowball the reference lists of the included studies to identify any further records we may have missed with the electronic databases. No further studies were added.

Insert Figure 2 about here

Studies were included if they satisfied the following a priori criteria: (a) it evaluated the effectiveness of an SDT-informed intervention-based program designed to foster autonomy-, competence-, or relatedness-supportive strategies to promote autonomous motivation in organizational contexts. For our purposes, we included different types of interventions: (e.g., leadership or employee training, work design programs), (b) the design of the study consisted of a randomized-controlled trial, quasi-controlled trial, or single cohort pre-post design (c) the context of the study was in organizations with adult employee samples or leaders; (d) the study was available in English.

While 10 studies for the systematic review is fewer than typical in organizational research, this decision is justified for several reasons. First, expanding our inclusion criteria to include more studies would mean broadening our review beyond organizational contexts. Second, a systematic review early in a literature's development means the review is likely to be more influential in steering future research in productive directions that address fundamental gaps, sources of bias, and limitations early in the research process (Gough et al., 2017). Finally, systematic reviews with a relatively small number of studies are common practice in some research fields. For example, the typical Cochrane systematic review contains only six studies (Mallet \& Clarke 2002), yet they remain instrumental in the evidence-based provision of healthcare. We expect that our review will be similarly informative in steering research and practice of need supportive interventions in work settings.

\section{Risk of Bias Assessment}

The included studies were independently evaluated by two authors using the Quality Assessment Tool for Quantitative Studies (QATQS, 2008) checklist, which evaluates studies for six areas of possible bias: (a) selection bias, (b) study design, (c) confounders, (d) blinding, (e) data 
collection methods, and (f) withdrawals and dropouts. Studies are evaluated on each area and assigned a quality score of (1) strong, (2) moderate, or (3) weak, which are then used to assign global risk of bias assessments of low (no weak ratings), moderate (one weak rating), and high (two or more weak ratings) for each study. The two authors coded each study for each assessment item and showed high interrater agreement (interrater correlation $|r|=.89$ ). Where differences in ratings emerged, they were resolved by discussion.

\section{Data Extraction and Coding}

We obtained a copy of the full text for each study that met our inclusion criteria. Using a systematic data extraction form, two authors proceeded to independently code each paper for each relevant item. Only three discrepancies in coding emerged and were resolved by discussion. Studies were coded on nine categories: (a) study design, (b) sample size, (c) year of the study, (d) type of control group utilized (if any), (e) nature of the intervention, (f) duration of the intervention, (g) number and length of follow-up assessments, (h) primary dependent variables, and (i) main findings. We summarized the main study findings as reported by paper authors, focusing on outcomes of need supportive interventions for both leaders and employees at each time-point. We also documented study design and training delivery characteristics across studies. Because study designs and dependent measures varied across studies, we did not employ meta-analysis to aggregate effect sizes.

\section{RESULTS}

The main characteristics and findings across each study are summarized in Table 1 . We organize the reporting of our results into three themes: (a) primary study findings, (b) possible moderators of effectiveness, and (c) risk of bias assessments.

Insert Table 1 about here

\section{Primary Study Findings}

Targeted Outcomes. Figure 3 provides an overview of the targeted outcomes across studies as well as the associated sampling strategies used. Like Figure 1, we overlay each stage of the 
research process onto the Kirkpatrick (1959) framework. Contrasted above and below the dashed horizontal line are the two broad types of studies in this literature. Above the line are studies that used multi-level sampling strategies (e.g., leadership-training studies; $\mathrm{n}=5$ ) that were designed to evaluate deeper levels of change (e.g., subordinate results). This means that they recruited samples at the proximal (e.g., leaders) and distal (e.g., subordinates) levels to assess the trickle-down of effects from leaders to subordinates. By contrast, below the dashed horizontal line are those that utilized single-level sampling $(n=4)$, which delivered the motivation-based intervention directly to employees who were later themselves evaluated post-intervention, thereby removing the capacity to examine the trickle-down of proximal to distal effects. Three of these studies used a training intervention delivered directly to employees (e.g., Jungert et al., 2018; Pedersen et al., 2018, 2019; Williams et al. 2016) whereas Stenling and Tafvelin (2016) only examined the leader sample. One study did not use a training intervention and instead embedded need supports into the work design of the organization (Smith et al., 2017).

Insert Figure 3 about here

Effectiveness of interventions at post-intervention and at follow-up. At post-intervention, seven of the 10 studies concluded that the interventions yielded beneficial outcomes (e.g., Deci et al., 1989; Hardré \& Reeve, 2009, Jungert et al., 2019; Pedersen et al., 2018, 2019; Smith et al., 2017; Stenling \& Tafvelin, 2016; Williams et al., 2016). Two studies concluded that interventions showed relatively mixed findings (e.g., Forner, 2019; Yong et al., 2019b), and one study concluded that there were no changes post-intervention (e.g., Tafvelin et al., 2019).

Post-intervention. Figure 3 shows which variables were measured and those that were sufficiently impacted post-intervention. Variables displayed with asterisks indicate those effects that emerged significant in more than one study. As shown in the figure, multi-level sampling interventions yielded proximal effects in leader participants (learning), including facilitating orientations towards autonomy supportiveness. No outcomes at the Kirkpatrick's reactions level were evaluated. Interventions also showed effects in transfer, including leader intentions to utilize 
intervention learnings on-the-job (Deci et al., 1989; Forner, 2019; Hardré \& Reeve, 2009; Yong et al., 2019b). For more distal results outcomes in subordinates, post-intervention effects were observed in perceptions of need supportive behavior (Deci et al., 1989), autonomous motivation and work engagement (Hardré \& Reeve, 2009). Few other effects were observed in multi-level sampling studies at the subordinate results level.

For studies that employed single-level sampling, again no studies evaluated outcomes at the reactions level. However, for learning criteria, significant post-intervention effects were observed in basic need satisfaction and autonomous motivation (Jungert et al., 2018; Pedersen et al., 2018, 2019; Williams et al., 2016), and job satisfaction (Smith et al., 2017). Pedersen et al. (2018, 2019) also observed physiological outcomes, including cardiorespiratory fitness, high-density lipoteins cholesterol, and diastolic blood pressure. For intervention transfer, Stenling and Tafvelin (2016) observed differences in leader intentions to utilize the intervention learnings.

Follow-up. Most of the studies included a follow-up assessment $(\mathrm{n}=6)$, yet the length of follow-up varied considerably, ranging from 2-months to 3-years (sample-size weighted mean = 43.01 weeks, $\mathrm{SD}=29.08)$. For multi-level sampling studies, Hardré and Reeve (2009) only used data that were collected at baseline and post-intervention, and Forner (2019) tracked only the leader sample over time. Thus, it was not possible for these studies to detect trickle-down effects from leaders to subordinate results that emerge over time. Notwithstanding this, sustained changes were observed in proximal (learning) outcomes, with leaders showing sustained improvements in autonomy supportive behavior (Deci et al., 1989; Forner et al., 1989). For distal subordinate results, Deci et al. (2001) observed sustained effects in trust of leadership, job satisfaction, and feeling nonpressured at work. No other long-term effects were observed. For single-level sampling studies, few reported follow-up effects. However, Smith et al. (2017) observed sustained changes in job satisfaction and basic need satisfaction.

\section{Possible Moderators of Effectiveness.}

Figure 3 also displays possible moderators of intervention effectiveness, which we group into proximal and distal effectiveness categories for multi-level sampling studies. We classify moderators 
of proximal effectiveness as factors thought to affect the intervention's ability to impart change (reactions, learning or transfer) in the proximal sample (leaders), whereas moderators of distal effectiveness are factors thought to impact the trickle-down of changes from the proximal sample to more distal subordinate results. Importantly, whether studies employed multi-level sampling strategies to examine trickle-down effects, and whether sufficient follow-up time was allowed emerged as likely moderators, which we turn to next.

\section{Sampling strategy and evaluation timeline.}

Multi-level sampling studies. For leadership-training studies that employed multi-level sampling, findings showed possible moderation by Kirkpatrick evaluation criteria, with studies generally yielding stronger results at the proximal level. For example, Hardré and Reeve (2009) showed moderate to strong improvements at post-intervention in those who received the training. Effect sizes ranged from moderate $(d=0.71)$ to large $(d=2.13)$ across four aspects of autonomysupportive leader behavior. Yet, for distal change in subordinates, more modest yet significant improvements were observed in amotivation $(d=0.39)$, external regulation $(d=0.44)$, autonomous motivation $(d=0.40)$ and work engagement $(d=0.37)$. Similar results were observed by Yong et al. (2019b) who found autonomy-supportive training increased autonomy-supportive behavior in the proximal leader sample, yet no distal changes were observed in subordinate results.

These results converged with Forner (2019), who delivered 2-days of need supportive training to leaders over a 9-week period. While leader participants showed increased autonomy supportiveness, which was sustained after a year, no changes were observed in subordinate basic needs, job satisfaction, or turnover intentions over the 9-week program. However, this study did not track the employee sample at the 1-year follow-up, meaning trickle-down effects may not have had time to materialize. Supporting this, Deci et al. (1989) showed autonomy supportive training shifted leader orientations towards greater autonomy support. At the distal level in subordinate results, orientations correlated with subordinate-level trust in the organization and job satisfaction across three time points spanning 1-year. Importantly, stronger correlations emerged over time (Trust: T1, $r$ $=.12 ; \mathrm{T} 3, r=.72 ;$ satisfaction: $\mathrm{T} 1, r=.03 ; \mathrm{T} 3, r=.69)$, again suggesting that effects of training 
took time to materialize at the subordinate level. Tafvelin et al. (2019) was the only study that concluded there were no proximal or distal benefits as a result of the intervention, with no significant improvements for leaders or subordinates, though this study only tracked employees over a relatively short period of two-months.

Single-level sampling studies. For studies that utilized single-level sampling, small to moderate, yet more consistently significant results were observed. For example, Jungert et al. (2018) and Pedersen et al. $(2018,2019)$ delivered need-supportive training directly to work-teams and employees, respectively, and found small to moderate effects in perceived need support and autonomous motivation. Pedersen et al. also showed some small effects in physiological outcomes, including diastolic blood pressure $(d=-0.26)$, high-density lipoproteins cholesterol $(d=0.12)$, and cardiorespiratory fitness $(d=0.39)$. Williams et al. (2016) delivered training to mental health workers and showed improvements in integrated motivation and plans to implement the learnings (learnings and transfer) in the intervention group. Smith et al. (2017) was the only study to embed their need support intervention into organizational work design via a gender-diversity program. Results showed that involvement with the program predicted small to moderate positive changes in basic need satisfaction, and job satisfaction 2-years after baseline. Finally, Stenling and Tafvelin (2016) examined leaders without evaluating trickle-down effects on employees. They showed that autonomy support during training did not predict near-transfer, defined as the extent to which leaders used their learnings directly after the training. However, it did predict far-transfer (1-year later). Thus, supporting multi-level sampling studies, it appears effects may take time to emerge.

\section{Proximal effectiveness}

We describe proximal effectiveness as the intervention's ability to yield desirable results in those who directly received the intervention (the proximal sample). As shown in Figure 3, in studies with multi-level sampling, this involved leaders who received training. In studies with single-level sampling, this involved employees who directly received the intervention.

Coverage of the interventions. Table 1 provides a summary of the types of strategies used to train basic need supportive behaviors in organizations. Most studies rolled out training derived 
exclusively from SDT: focusing on autonomy support (e.g., providing choice and maximizing opportunities for initiative-taking) competence support (e.g., provision of constructive feedback; creating challenge, using informational language), and relatedness support (e.g., fostering perspective taking, communication skills, interpersonal involvement strategies). Some studies combined SDTbased training with other training (e.g., general HR procedures; Stenling \& Tafvelin, 2016) or other types of therapy, such as the Collaborative Recovery Model (Williams et al., 2016). Interventions most commonly focused on autonomy support, of which strategies were covered in all studies. Competence supporting strategies were covered in six studies, mostly focusing on training competence-building feedback. Relatedness supports were clearly covered in three studies (Jungert et al., 2018; Smith et al., 2017; Williams et al., 2016). Tafvelin et al. (2019) noted they trained leaders in all three techniques but did not provide details about strategies used.

Pedagogy and implementation. Studies varied in pedagogical strategies and implementation, with some more closely aligning with need supportive techniques. For example, some studies included one-on-one consultations with experts to support the intervention's roll out (e.g., Deci et al., 1989; Hardré \& Reeve, 2009; Pedersen et al., 2019), which may enhance perceived competence to implement the learned behaviors. Other studies used variations of this, such as peer-support (Pederson et al, 2018, 2019). Similarly, some studies (e.g., Deci et al., 1989; Jungert et al., 2018; Williams et al., 2016) used reflective exercises (e.g., Deci et al., 1989; Jungert et al., 2018) with a view towards aligning current behaviors with need supportive techniques. Other approaches used in the interventions were question and answer sessions (Hardré \& Reeve, 2009), small group activities (e.g., Hardré \& Reeve, 2009, Jungert et al, 2018; Pederson et al., 2019), and self-directed study (Hardré \& Reeve, 2009). Some studies used strategies that were less aligned with supporting basic needs. Tafvelin et al. (2019), for example, mandated attendance, which may have contributed to the lack of commitment observed in this study due to a lack of autonomy.

Context and participant characteristics. Contextual factors were offered as possible moderators of effectiveness, some of which emerged from qualitative data. For example, through qualitative observations, Tafvelin et al. (2019) uncovered possible reasons their intervention showed 
little effect. This included (a) lack of individualized consideration about the unique work context, (b) poor organizational integration of the intervention with limited buy-in from senior management, and (c) lack of commitment from the training participants themselves due to operational demands conflicting training requirements. Individual difference characteristics were also shown to moderate effectiveness, including leader experience. For example, Forner (2019) observed that less experienced leaders benefited more from training than experienced leaders, potentially because entrenched leader behaviors have had less opportunity to crystalize at early career stages. This finding converges with Yong et al. (2019b), who showed leaders revert to controlling practices if such practices had worked for them in the past.

Intervention duration. We explored whether the length of training ("dose") emerged as a possible moderator. Results showed intervention length to vary considerably across studies, from 2hours (Hardré \& Reeve, 2009) to six days (Stenling \& Tafvelin, 2016). Despite this heterogeneity, length of training did not appear to be critical in contributing to intervention effectiveness, with some studies offering 2-hours to 1-day of training yielding stronger effects (e.g., Hardré \& Reeve, 2009; Pedersen et al., 2018, 2019) than interventions lasting several days (e.g., Tafvelin et al., 2019). However, it is worth noting that shorter interventions (Hardré \& Reeve, 2009; Pedersen et al., 2018, 2019) were typically supplemented with one-on-one consultations.

\section{Distal effectiveness.}

We describe distal effectiveness as the intervention's ability to yield desirable trickle-down results in the distal sample. In our included studies, this involved the subordinates who reported to the leaders, the latter being the sample who received the training. As shown in Figure 3, distal effectiveness could not be examined in studies with single-level sampling due to the absence of a distal sample. Across studies, qualitative analyses pointed to factors that potentially contributed to the lack of improvements at a distal level. Most central appeared to be leader participants reporting inconsistent and infrequent contact with their subordinates due to interdepartmental movements and shift work (e.g., Yong et al., 2019b). This infrequency was thought to impede trickle-down effects from leaders to subordinates, even if interventions were effective at a proximal level. Infrequent 
contact between leaders and subordinates was also thought to limit distal effectiveness in other studies (e.g., Deci et al., 1989). Other possible contributors were pressures placed on supervisors to command quick results, lacking resources, as well as existing beliefs about the benefits of need supportive leadership.

\section{Risk of Bias Assessments}

Our risk of bias assessments can be observed in our supplemental file, with our checklist indicating that bias was moderate or high across studies. Accordingly, results of interventions need to be interpreted with some caution, particularly across three areas. First, blinding emerged as an area of bias; no study blinded participants to condition. In most cases this was not possible because the study control-groups did not receive training during the study. While Williams et al. (2016) used an active control group, these authors noted that participants were unable to be blinded. Addressing confounders emerged as another area for potential bias. Most studies did not indicate whether there were baseline factors that could influence the outcomes of the intervention and did not control for such factors. Finally, withdrawals and dropouts emerged as another area for potential bias; most studies did not report withdrawals or dropouts or did not use related principles for data-analysis. The one exception was Pederson et al. $(2018,2019)$, which took full account of attrition using intent-totreat analyses. An area of strength across studies was that eight used comparison groups, allowing for stronger causal inferences (Cook \& Campbell, 1979).

\section{DISCUSSION}

The aim of the present research was to provide a comprehensive qualitative review of the literature investigating interventions to engender support for autonomy, competence, and relatedness needs and, in turn, autonomous motivation in organizations. From our findings across ten intervention studies, we offer recommendations that we expect will help to establish reliable, informative, and consistent findings in this literature. In the following sections, we review major themes of the study and offer recommendations to advance empirical research and practice. We start with our recommendations for research and distinguish those that will help to establish the "when" 
(evaluation timelines), the "how" (methods), and the "what" (content) of intervention effectiveness in terms of impacting employee well-being.

\section{The "When" of Intervention Effectiveness.}

\section{Recommendation 1: Consider distal outcome criteria in intervention evaluation. To} detect intervention effectiveness at deeper and more distal levels of change (Kirkpatrick, 1959), it generally requires two levels of sampling so that down-stream and more distal effects can be observed (see Figure 1). Half of the studies we reviewed employed this strategy, likely because these studies focused on leadership training as a route to promote basic needs. Other studies, which used more direct strategies, such as employee training or embedding the intervention into work design, generally did not evaluate distal effects. This may be an issue to the extent that interventions are more effective at yielding proximal than distal effects, a postulation for which our review lends some support. This makes more sense when one considers distal changes are contingent on intermediary steps, such as the accumulation of leader-subordinate interactions over time (Deci et al., 1989; Forner, 2019; Yong et al., 2019b). It will be important for future work to assess these different outcome criteria so that such nuances can be incorporated into future meta-analytic studies, which is required to yield reliable and meaningful information.

Recommendation 2: Assess long-term follow-up. An important limitation to emerge from the literature was that, while most studies tracked changes over time, most did not employ long-term follow-up assessments. We expect that this is a particular issue for leadership training studies that utilize multi-level sampling to assess subordinate results outcomes, due to a possible sleeper effect. A sleeper effect occurs when interventions show more effectiveness only after a period of incubation (Frese \& Zapf, 1988; Nesselroade, 1991). While sleeper effects are more established in persuasion research (Kumkale \& Albarracin, 2004), they are also observed in applied settings (Bry et al., 1986; Bry \& Krinsley, 1992; van Wingerden et al., 2017).

In our review, studies showed consistent and, in some cases, stronger effects of need supportive interventions after a time-lag (e.g., Deci et al., 1989; Forner, 2019; Pedersen et al., 2018, 2019; Stenling \& Tafvelin, 2016). Similarly, studies that tracked participants over short-periods of 
time either failed to detect an effect at the most distal subordinate results level (e.g., Forner, 2019; Tafvelin et al., 2019; Yong et al., 2019b) or observed only small effects (e.g., Hardré \& Reeve, 2009). Accordingly, studies that do not track participants over time may fail to detect delayed effects, which future research should seek to address. We suggest that this is especially important for interventions following the multi-level sampling process depicted in Figure 1.

\section{The "How" of Intervention Effectiveness.}

Recommendation 3: Resolve methodological challenges that bias causal inferences. Our risk of bias assessments indicated that bias was moderate or high across studies, and future research will need to overcome these challenges. Issues to resolve are taking steps to control for known prognostic variables from baseline (e.g., relevant demographics, individual differences), as well as accounting for attrition using approaches that avoid the bias associated with non-random loss of data over-time (e.g., intent-to-treat; Schulz et al., 2010). We also suggest more studies utilize typical or clustered RCT designs that allow more confidence in internal validity and thus stronger inferences about causality (e.g., Hardré \& Reeve, 2009; Pedersen et al., 2018, 2019; Williams et al., 2016), particularly with active control groups, which may help to overcome potential impediments to blinding. At this early stage of the research literature, it may also benefit studies to adopt mixed methods designs to capture richer data on participant reactions, learning, and transfer (e.g., Tafvelin et al., 2019; Yong et al, 2019b), which can be instrumental in identifying factors associated with intervention success. In sport settings, for example, mixed methods have provided insights into contextual issues that affect the efficacy of the intervention (Mahoney et al., 2016) and transfer of knowledge (Cheon \& Reeve, 2013; Langan et al., 2015).

\section{The "What" of Intervention Effectiveness.}

\section{Recommendation 4: Examine broad strategies to support basic needs. Our review} showed all interventions trained participants in autonomy support, with fewer exploring the additive benefit of competence or relatedness supportive techniques. We expect this may be due to the more established historical body of research on autonomy support in SDT (Deci et al., 1981, 1989; Deci \& Ryan, 1987), with several existing reviews exclusively focusing on this approach alone (e.g., Slemp 
et al., 2018; Su \& Reeve, 2011). Autonomy support is also thought to nurture all three basic needs, not just the need for autonomy (Ryan \& Deci, 2017), given it allows employees to more effectively self-govern how they pursue competence (e.g., feedback), and relatedness (e.g., networking) supportive activities. Notwithstanding this, we suggest a fruitful avenue for future work is to examine the incremental benefit of incorporating competence and relatedness supports into interventions. While some studies utilized strategies to encompass all three techniques (e.g., Smith et al., 2017; Tafvelin et al., 2019) there currently remains insufficient evidence to conclude such strategies enhance intervention effectiveness. In a similar vein, future intervention research should also explore the additive benefit of incorporating strategies to reduce need thwarting behaviors (micromanagement, controlling use of incentives) that are known to frustrate basic needs (Vansteenkiste \& Ryan, 2013). Evidence suggests need thwarting and need supporting approaches comprise related, yet distinct constructs (Haerens et al., 2018), and may be complementary. Establishing whether these broader strategies exhibit incremental benefit in employee functioning will either allow for greater parsimony in intervention design, or enhanced effectiveness.

Equally, most interventions targeted the social context (leader behavior) to foster need supportive environments. Other studies targeted employees directly (e.g., Williams et al., 2016; Pedersen et al. 2018, 2019), but none targeted the combination of leader and employee behavior as potentially mutually supportive ways to foster employee basic needs and autonomous motivation. A growing literature suggests that employee proactive behavior strategies (e.g., job crafting, playful work design; Bakker \& Oerlemans, 2019; Bakker \& van Woerkom, 2017) offer alternative paths to basic need satisfaction (Bakker \& van Woerkom, 2017; Slemp \& Vella-Brodrick, 2014). Research also suggests such strategies interact with leadership and provide employees with self-directed ways to potentially manufacture more need supportive behavior in their leader (Slemp et al., 2015, 2020b). Future research should thus explore how such strategies can be built into need supportive interventions, and whether they similarly offer incremental benefit in employee functioning.

Recommendation 5: Consider more standardization in content and implementation.

Our review revealed substantial heterogeneity in the length, format, and content of interventions. 
While highly tailored interventions can help to aid relevance across unique work contexts and may enhance ecological validity, it may also conceal the ability to determine the primary contributors to treatment effects (Hoffman et al., 2014; Mars et al., 2013). The observed heterogeneity in interventions is likely to stem from the lack of a standardized intervention protocol or conceptual guidelines against which researchers can maintain 'fidelity to treatment', which refers to methodological strategies to monitor and evaluate whether an intervention is delivered as intended or differentiated from a standardized approach (Bellg et al., 2004). Fidelity to treatment is facilitated when treatment protocols standardize the most core characteristics of an intervention, thereby facilitating the ability to generalize about the most essential causal contributors to the treatment effect (Hoffman et al., 2014). Standardization also helps to establish the adequate testing of research hypotheses, replicability of research, lessen type II errors in research (Prowse et al., 2015), and increases effectiveness (Lacerenza et al., 2017).

We suggest a fruitful direction for future work is to establish a standardized conceptual framework to guide the implementation of need supportive training to leaders and employees in organizations. This suggestion is not new, with researchers focusing on SDT making calls for comparable guidelines in related literatures. For example, Langdon et al. (2015) called for guidelines about specific examples to implement need supportive behaviors in sports settings, which gave rise to programs such as the Motivation Activation Program in Sports (MAPS; Bernsten \& Kristiansen, 2019). A qualitative review of MAPS revealed greater effectiveness demanded sufficient time for individual athletes, a gradual approach to athlete understanding, and thorough consideration of unique situations where skills could be applied (Bernsten \& Kristiansen, 2019). Such insights require a more standardized approach to intervention content and implementation, and we suggest this may benefit future research examining similar interventions in organizations.

While it is beyond the scope of the current review to establish a full conceptual framework to guide future interventions, we expect that our model presented in Figure 3 will aid this pursuit. While many of the observations in the figure will need to be replicated in future research, we expect that approaches shown to be effective across several studies, such one-on-one support, reflection 
exercises, individualized consideration of context, and use of appropriate evaluation timelines may enhance effectiveness and could be built into more standardized recommendations. We turn to some of these issues in our recommendations for practice.

\section{Recommendations for Practice}

Our findings contribute to practice in several ways. Below, we offer several recommendations that we believe will allow practitioners to actualize current evidence-based practice in intervention planning, implementation, and evaluation.

Recommendation 1: Proactively consider work pressures and broader context. A factor thought to undermine interventions was controlling behaviors exhibited from senior leadership (Tafvelin et al., 2019; Yong et al., 2019b). Similarly, internal pressures (e.g., interdepartmental demands) and external pressures (e.g., customer demands) shared similar consequences, potentially by burdening training participants with added demands that trigger default leadership styles. This may particularly be the case for experienced leaders who hold more entrenched approaches to leadership that are less malleable to change (e.g., Forner, 2019; Lacerenza et al., 2017). We suggest practitioners should proactively consider work pressures and ways in which program participants can manage them to avoid foregoing intervention learnings in favor of more ingrained leadership behaviors that are less supportive of employee basic needs. This might involve proactively identifying situations that will prompt more controlling leadership styles, an approach that has been effective in classrooms (Brophy, 1999; Pelletier et al., 2002; Reeve, 2002; Sarrazin et al., 2006). It also might involve giving choice where possible (e.g., voluntary participation), or incorporating approaches to reduce need-thwarting (controlling) behaviors, an approach that has been effective in both sport and physical education interventions (e.g., Aelterman et al., 2014; Cheon et al., 2013; Langdon et al., 2015). Consideration of such broader context factors is fundamental to intervention effectiveness and should be considered in implementation (Moore et al., 2019).

\section{Recommendation 2: Give preference to pedagogy and implementation that supports}

basic needs. Studies varied in their approaches to pedagogy and implementation, with some using strategies aligned with supporting basic needs. Beneficial approaches appeared to be self-reflections 
and one-on-one consultations, which were used across several successful studies. In self-reflection activities, participants are encouraged to introspectively examine, question, and critique their approach, which could build competence and is known to aid the internalization process (Ryan \& Deci, 2004). Such exercises were used in several interventions that showed significant benefits (Deci et al., 1989; Jungert et al., 2018; Williams et al., 2016). Similarly, one-on-one consultations with expert consultants were used in several studies (Deci et al., 1989; Hardré \& Reeve, 2009; Pedersen et al., 2019), potentially providing another avenue for competence support (Ryan \& Deci, 2017). Consultations may also aid contextualization to the participant's setting (Lacerenza et al., 2017). Future studies might consider techniques that could serve similar and complementary purposes. Knittle et al. (2020), for example, offer a compendium of techniques to support motivation for behavior change, some of which could promote self-endorsement and competence for the desired behaviors and may thus aid internalization of the training (e.g., behavioral demonstrations, demonstrating vicarious consequences for behaviors, identifying sources of social support).

By contrast, some forms of pedagogy may have been less effective at supporting basic needs. Tafvelin et al. (2019), for example, had participants give presentations about subordinate feedback on their personal leadership approach, the public display of which may have stimulated experiences associated with controlled motivation (e.g., shame, guilt, social comparison). This intervention also used mandatory participation, potentially undermining participant autonomy. While mandatory participation increases participation rates (Lacerenza et al., 2017), we suggest a more effective strategy is to increase participation by identifying ways voluntary training can be made more appealing to leaders and employees, potentially by highlighting tangible benefits. This approach is more conducive to autonomous motivation to participate and thus self-endorsement of the intervention from the outset.

Recommendation 3: Align interventions with stakeholder needs. In some studies, participants were not necessarily committed to the training (Tafvelin et al., 2019), in some cases because they could not see the relevance to their work context. Thus, practitioners might consider ways to visibly align interventions with the strategic directions of the organization or other 
stakeholder needs, potentially by conducting a needs analysis. A needs analysis tends to increase leadership training effectiveness (Lacerenza et al., 2017), and might be achieved by working with stakeholders, allowing time for planning, and addressing barriers to alignment at the outset (Tafvelin et al., 2019; Yong et al., 2019b). Smith et al. (2017) offer some example approaches. These authors integrated their intervention into the objectives deemed important within their university context (e.g., competence supportive approaches designed to develop grant application skills; Table 1). Such alignment may elevate the relevance and commitment towards the intervention because it allows participants to more easily see how it benefits them, potentially mitigating resistance from important stakeholders - another factor suggested to have limited effectiveness.

Recommendation 4: Resist focusing only on short-term effects. Our synthesis suggests that while studies were generally effective at yielding beneficial outcomes, effectiveness was likely moderated by the Kirkpatrick evaluation criteria, with small or null findings generally observed at the subordinate level. We expect this is related to follow-up length. With our review showing stronger results can emerge over time, it will be important for practitioners to ensure sufficient time is allocated to evaluate the emergence of results after sufficient incubation. An aid to this may be the use of follow-up, booster sessions to reinforce learnings over time, a strategy that was successfully used in some studies (e.g., Forner, 2019; Hardré \& Reeve, 2009; Pedersen et al., 2018, 2019), and is a recommended approach in training interventions (Lacerenza et al., 2018). Repeated training sessions may also aid the proactive management of obstacles to implementation as they occur.

\section{Limitations}

It is important to acknowledge some limitations with the present study. Most notably, our review is limited to the observations of 10 studies, which is fewer than is typical in organizational research (e.g., Eby et al., 2019; Eva et al., 2019; Newman et al., 2019). This limited our ability to comprehensively explore factors that affect intervention effectiveness as we could not statistically examine moderators across studies. While we could have broadened our inclusion criteria to include a wider set of interventions outside the conceptual terrain of SDT that might also impact basic needs (e.g., job crafting interventions, strengths interventions; see Bakker \& van Woerkom, 2017; Slemp \& 
Vella-Brodrick, 2014), we did not do this for two reasons. First, such interventions are typically not informed by SDT and thus were not designed for the specific purpose of supporting basic needs, despite the conceptual link. The studies we included, in contrast, are directly derivative of SDTbased theorizing of practices to engender support for basic needs and, in turn, autonomous motivation. Second, broadening the inclusion criteria would likely have resulted in unclear boundaries for inclusion. One could reasonably argue, for example, that any form of workplace training intervention should elevate perceived competence, and thus would need to be included in the review. Still, this decision limited the number of studies we included, and we note that many of the conclusions discussed in this paper and depicted in Figure 3, are based on the observations of relatively few studies, with some emerging from qualitative data. We expect that this will present an opportunity for future quantitative replication work.

An upshot of this limitation is that we did not employ meta-analysis to aggregate effect sizes. Before meta-analyses can be performed, the literature will need to resolve some methodological challenges in order to return meaningful information. Most notably, additional studies are needed that share research design characteristics to overcome the problems caused by aggregating studies of different designs (e.g., randomized and non-randomized studies), which is known to artificially inflate meta-analytic effect sizes (Higgins \& Green, 2011). In addition, aggregating studies that utilize different comparison referents (e.g., within-group vs. between-group) only serves to yield meta-analytic effect sizes that are uninterpretable (Borenstein et al., 2009; Schmidt \& Hunter, 2015). Thus, to yield meaningful information, study designs need to be separated to recognize this difference. We also expect that our call for more standardized recommendations to guide what is included and excluded from interventions will aid fidelity to treatment, thereby enhancing the reliability of future meta-analytic data. We anticipate that our review will be informative in steering research and practice in productive directions at this relatively early stage of the literature's development. 


\section{REFERENCES}

Studies marked with an asterisk $(*)$ were included in the systematic review

Aelterman, N., Vansteenkiste, M., Van den Berghe, L., De Meyer, J., \& Haerens, L. (2014). Fostering a need-supportive teaching style: Intervention effects on physical education teachers' beliefs and teaching behaviors. Journal of Sport and Exercise Psychology, 36(6), 595-609.

Allinson, C. W., Armstrong, S. J., \& Hayes, J. (2001). The effects of cognitive style on leader-member exchange: A study of manager-subordinate dyads. Journal of Occupational and Organizational Psychology, 74(2), 201-220.

Bakker, A. B., \& Oerlemans, W. G. (2019). Daily job crafting and momentary work engagement: A self-determination and self-regulation perspective. Journal of Vocational Behavior, 112, 417430.

Bakker, A. B., \& Schaufeli, W. B. (2008). Positive organizational behavior: Engaged employees in flourishing organizations. Journal of Organizational Behavior, 29(2), 147-154.

Bakker, A. B., \& van Woerkom, M. (2018). Strengths use in organizations: A positive approach of occupational health. Canadian Psychology, 59(1), 38-46.

Baumeister, R. F., \& Leary, M. R. (1995). The need to belong: Desire for interpersonal attachments as a fundamental human motivation. Psychological Bulletin, 117(3), 497-529.

Beehr, T. A. (2019). Interventions in occupational health psychology. Journal of Occupational Health Psychology, 24(1), 1-3.

Bellg, A. J., Borrelli, B., Resnick, B., Hecht, J., Minicucci, D. S., Ory, M., ... \& Czajkowski, S. (2004). Enhancing treatment fidelity in health behavior change studies: Best practices and recommendations from the NIH Behavior Change Consortium. Health Psychology, 23(5), 443.

Berntsen, H., \& Kristiansen, E. (2019). Guidelines for need-supportive coach development: the motivation activation program in sports (MAPS). International Sport Coaching Journal, 6(1), 88-97.

Bindl, U. K., Unsworth, K. L., Gibson, C. B., \& Stride, C. B. (2019). Job crafting revisited: Implications of an extended framework for active changes at work. Journal of Applied Psychology, 104(5), 605-628.

Borenstein, M., Cooper, H., Hedges, L., \& Valentine, J. (2009). Effect sizes for continuous data. The handbook of research synthesis and meta-analysis, 2, 221-235.

Brophy, J. (1999). Advances in motivation and achievement. The role of context In T. Udran (Ed.), Research on motivation in education: past, present, and future. (pp. 1-44). New York: JAI Press

Bry, B. H., \& Krinsley, K. E. (1992). Booster sessions and long-term effects of behavioral family therapy on adolescent substance use and school performance. Journal of Behavior Therapy and Experimental Psychiatry, 23, 183-189. doi:10.1016/0005-7916(92)90035-H

Bry, B. H., Conboy, C., \& Bisgay, K. (1986). Decreasing adolescent drug use and school failure: Long-term effects of targeted family-problem solving training. Child \& Family Behavior Therapy, 8, 43-60. doi:10.1300/ J019v08n01_03

Cheon, S. H., \& Reeve, J. (2013). Do the benefits from autonomy-supportive PE teacher training programs endure?: A one-year follow-up investigation. Psychology of Sport and Exercise, 14(4), 508-518.

Chong, J. X., Beenen, G., Gagné, M., \& Dunlop, P. D. (2020). Satisfying Newcomers' Needs: The Role of Socialization Tactics and Supervisor Autonomy Support. Journal of Business and Psychology, 1-17. 
Cook, T. D., \& Campbell, D. T. (1979). The design and conduct of true experiments and quasiexperiments in field settings. In Reproduced in part in Research in Organizations: Issues and Controversies. Goodyear Publishing Company.

Crowe, T. P., Deane, F. P., Oades, L. G., Caputi, P., \& Morland, K. G. (2006). Effectiveness of a collaborative recovery training program in Australia in promoting positive views about recovery. Psychiatric Services, 57(10), 1497-1500.

* Deci, E. L., Connell, J. P., \& Ryan, R. M. (1989). Self-determination in a work organization. Journal of Applied Psychology, 74(4), 580.

Deci, E. L., Eghrari, H., Patrick, B. C., \& Leone, D. R. (1994). Facilitating internalization: The selfdetermination theory perspective. Journal of Personality, 62(1), 119-142.

Deci, E. L., Olafsen, A. H., \& Ryan, R. M. (2017). Self-determination theory in work organizations: The state of a science. Annual Review of Organizational Psychology and Organizational Behavior, 4, 19-43.

Deci, E. L., \& Ryan, R. M. (1985). The general causality orientations scale: Self-determination in personality. Journal of Research in Personality, 19, 109-134.

Deci, E. L., \& Ryan, R. M. (1987). The support of autonomy and the control of behavior. Journal of Personality and Social Psychology, 53(6), 1024-1037.

Deci, E. L., \& Ryan, R. M. (2000). The" what" and" why" of goal pursuits: Human needs and the selfdetermination of behavior. Psychological Inquiry, 11(4), 227-268.

Deci, E. L., Ryan, R. M., Gagné, M., Leone, D. R., Usunov, J., \& Kornazheva, B. P. (2001). Need satisfaction, motivation, and well-being in the work organizations of a former eastern bloc country: A cross-cultural study of self-determination. Personality \& Social Psychology Bulletin, 27(8), 930-942.

Deci, E. L., Schwartz, A. J., Sheinman, L., \& Ryan, R. M. (1981). An instrument to assess adults' orientations toward control versus autonomy with children: Reflections on intrinsic motivation and perceived competence. Journal of Educational Psychology, 73(5), 642-650.

Eby, L. T., Allen, T. D., Conley, K. M., Williamson, R. L., Henderson, T. G., \& Mancini, V. S. (2019). Mindfulness-based training interventions for employees: A qualitative review of the literature. Human Resource Management Review, 29(2), 156-178.

Epitropaki, O., \& Martin, R. (1999). The impact of relational demography on the quality of leadermember exchanges and employees' work attitudes and well-being. Journal of Occupational and Organizational Psychology, 72(2), 237-240.

Eva, N., Robin, M., Sendjaya, S., van Dierendonck, D., \& Liden, R. C. (2019). Servant leadership: A systematic review and call for future research. The Leadership Quarterly, 30(1), 111-132.

Fernet, C., Austin, S., \& Vallerand, R. J. (2012). The effects of work motivation on employee exhaustion and commitment: An extension of the JD-R model. Work \& Stress, 26(3), 213-229.

* Forner, V. (2019). Reducing turnover in volunteer organisations: A leadership intervention based on self-determination theory (Doctoral dissertation, The University of Wollongong).

Frese, M., \& Zapf, D. (1988). Methodological issues in the study of work stress: Objective versus subjective measurement of work stress and the question of longitudinal studies. In C. L. Cooper $\&$ R. Payne (Eds.), Causes, coping, and consequences of stress at work (pp. 375-411). Chichester: Wiley.

Gagné, M. (2003). The role of autonomy support and autonomy orientation in prosocial behavior engagement. Motivation and Emotion, 27(3), 199-223.

Gagné, M., \& Deci, E. L. (2005). Self- determination theory and work motivation. Journal of Organizational Behavior, 26(4), 331-362. 
Gillison, F. B., Rouse, P., Standage, M., Sebire, S. J., \& Ryan, R. M. (2019). A meta-analysis of techniques to promote motivation for health behaviour change from a self-determination theory perspective. Health Psychology Review, 13(1), 110-130.

Gough, D., Oliver, S., \& Thomas, J. (Eds.). (2017). An Introduction to Systematic Reviews. Sage. Haerens, L., Vansteenkiste, M., De Meester, A., Delrue, J., Tallir, I., Vande Broek, G., Goris, W., \& Aelterman, N. (2018). Different combinations of perceived autonomy support and control: Identifying the most optimal motivating style. Physical Education and Sport Pedagogy, 23(1), 16-36.

* Hardré, P. L., \& Reeve, J. (2009). Training corporate managers to adopt a more autonomysupportive motivating style toward employees: An intervention study. International Journal of Training and Development, 13(3), 165-184.

Higgins, J. P., \& Green, S. (Eds.). (2011). Cochrane handbook for systematic reviews of interventions (Vol. 4). John Wiley \& Sons.

Hoffmann, T. C., Glasziou, P. P., Boutron, I., Milne, R., Perera, R., Moher, D., ... \& Lamb, S. E. (2014). Better reporting of interventions: template for intervention description and replication (TIDieR) checklist and guide. BMJ, 348, g1687.

Howard, J. L., Gagné, M., \& Bureau, J. S. (2017). Testing a Continuum Structure of Self-Determined Motivation: A Meta-Analysis. Psychological Bulletin, 143(12), 1346-1377.

* Jungert, T., Van den Broeck, A., Schreurs, B., \& Osterman, U. (2018). How colleagues can support each other's needs and motivation: An intervention on employee work motivation. Applied Psychology, 67(1), 3-29.

Kirkpatrick, D. (1959). Techniques for evaluating training programs. Journal of the American Society for Training and Development, 13, 3-9.

Kumkale, G. T., \& Albarracín, D. (2004). The sleeper effect in persuasion: a meta-analytic review. Psychological Bulletin, 130(1), 143-172.

Lacerenza, C. N., Reyes, D. L., Marlow, S. L., Joseph, D. L., \& Salas, E. (2017). Leadership training design, delivery, and implementation: A meta-analysis. Journal of Applied Psychology, 102(12), 1686-1718.

Langan, E., Lonsdale, C., Blake, C., \& Toner, J. (2015). Testing the Effects of a Self-Determination Theory-Based Intervention with Youth Gaelic Football Coaches on Athlete Motivation and Burnout. Sport Psychologist, 29(4), 293-301.

Langdon, J., Schlote, R., Harris, B., Burdette, G., \& Rothberger, S. (2015). Effects of a training program to enhance autonomy supportive behaviors among youth soccer coaches. Journal of Human Sport \& Exercise, 10(1), 1-14. doi:10.14198/jhse.2015.101.01

Mageau, G. A., \& Vallerand, R. J. (2003). The coach-athlete relationship: a motivational model. Journal of Sports Sciences, 21(11), 883-904.

Mahoney, J. W., Ntoumanis, N., Gucciardi, D. F., Mallett, C. J., \& Stebbings, J. (2016). Implementing an Autonomy-Supportive Intervention to Develop Mental Toughness in Adolescent Rowers. Journal of Applied Sport Psychology, 28(2), 199-215.

Mallett, S., \& Clarke, M. (2002). The typical Cochrane review: how many trials? how many participants? International Journal of Technology Assessment in Health Care, 18(4), 820-823.

Mars, T., Ellard, D., Carnes, D., Homer, K., Underwood, M., \& Taylor, S. J. (2013). Fidelity in complex behaviour change interventions: a standardised approach to evaluate intervention integrity. BMJ open, 3(11), e003555.

Moore, G. F., Evans, R. E., Hawkins, J., Littlecott, H., Melendez-Torres, G. J., Bonell, C., \& Murphy, S. (2019). From complex social interventions to interventions in complex social systems: Future 
directions and unresolved questions for intervention development and evaluation. Evaluation, 25(1), 23-45.

Nesselroade, J. R. (1991). Interindividual differences in intraindividual change. In L. M. Collins \& J. L. Horn (Eds.), Best methods for the analysis of change: Recent advances, unanswered questions, future directions (pp. 92-105). Washington, DC: American Psychological Association.

Newman, A., Round, H., Wang, S., \& Mount, M. (2020). Innovation climate: A systematic review of the literature and agenda for future research. Journal of Occupational and Organizational Psychology, 93(1), 73-109.

Ntoumanis, N., Ng, J. Y., Prestwich, A., Quested, E., Hancox, J. E., Thøgersen-Ntoumani, C., Deci, E., L., Ryan, R. M., Lonsdale, C., \& Williams, G. C. (2020). A meta-analysis of selfdetermination theory-informed intervention studies in the health domain: Effects on motivation, health behavior, physical, and psychological Health. Health Psychology Review, (2020), 1-85.

* Pedersen, C., Halvari, H., \& Olafsen, A. H. (2019). Worksite physical activity intervention and somatic symptoms burden: The role of coworker support for basic psychological needs and autonomous motivation. Journal of Occupational Health Psychology, 24(1), 55-65.

* Pedersen, C., Halvari, H., \& Williams, G. C. (2018). Worksite intervention effects on motivation, physical activity, and health: A cluster randomized controlled trial. Psychology of Sport and Exercise, 35, 171-180.

Pelletier, L., Séguin-Lévesque, C., \& Legault, L. (2002). Pressure from above and pressure from below as determinants of teachers' motivation and teaching behaviors. Journal of Educational Psychology, 94, 186-196.

Pinder, C. C. (2014). Work Motivation in Organizational Behavior. Psychology Press.

Prowse, P. T. D., Nagel, T., Meadows, G. N., \& Enticott, J. C. (2015). Treatment fidelity over the last decade in psychosocial clinical trials outcome studies: A systematic review. Journal of Psychiatry, 18(2), 1-8..

QATQS (2008). Quality Assessment Tool for Quantitative Studies (QATQS): National Collaborating Centre for Methods and Tools.. Hamilton, ON: McMaster University.

Reeve, J. (2002). Self-determination theory applied to educational setting. In E. L. Deci, \& R. M. Ryan (Eds.), Handbook of Self-Determination Research (pp. 183-203). Rochester, New York: University of Rochester Press.

Roberts, L. M. (2006). Shifting the lens on organizational life: The added value of positive scholarship. Academy of Management Review, 31(2), 292-305.

Ryan, R. M. (1995). Psychological needs and the facilitation of integrative processes. Journal of Personality, 63(3), 397-427.

Ryan, R. M., \& Connell, J. P. (1989). Perceived locus of causality and internalization: Examining reasons for acting in two domains. Journal of Personality and Social Psychology, 57(5), 749761.

Ryan, R. M., \& Deci, E. L. (2000). Self-determination theory and the facilitation of intrinsic motivation, social development, and well-being. American Psychologist, 55(1), 68.

Ryan, R. M., \& Deci, E. L. (2004). Autonomy is no illusion: Self-determination theory and the empirical study of authenticity, awareness, and will. In J. Greenberg, S. L. Koole, and T. Pyszczynski (Eds.), Handbook of Experimental Existential Psychology (pp. 449-479). Guilford Publications. https://ebookcentral.proquest.com/lib/unimelb/detail.action?docID=330563.

Ryan, R. M., \& Deci, E. L. (2017). Self-determination theory: Basic psychological needs in motivation, development, and wellness. Guilford Publications. 
Sarrazin, P., Tessier, D., Pelletier, L., Trouilloud, D., \& Chanal, C. (2006). The effects of teachers' expectations about students' motivation on teacher's autonomy-supportive and controlling behavior. International Journal of Sport and Exercise Psychology, 4, 283-301.

Schmidt, F. L., \& Hunter, J. E. (2015). Methods of meta-analysis: Correcting error and bias in research findings (3rd ed.). Thousand Oaks, CA: Sage.

Schulz, K. F., Altman, D. G., Moher, D., \& Consort Group. (2010). CONSORT 2010 statement: Updated guidelines for reporting parallel group randomised trials. BMJ, 340, 698-702.

Slemp, G. R., (2017). Job Crafting. In L. G. Oades, M. Steger, A. Delle Fave, \& J. Passmore (Eds.), The Wiley Blackwell Handbook of The Psychology of Positivity and Strengths-Based Approaches at Work (pp. 342 - 365). UK: John Wiley \& Sons.

Slemp, G. R., \& Vella-Brodrick, D. A. (2014). Optimising employee mental health: The relationship between intrinsic need satisfaction, job crafting, and employee well-being. Journal of Happiness Studies, 15(4), 957-977.

Slemp, G. R., Field, J. G., \& Cho, A. S. (2020a). A meta-analysis of autonomous and controlled forms of teacher motivation. Journal of Vocational Behavior, 103459.

Slemp, G. R., Kern, M. L., \& Vella-Brodrick, D. A. (2015). Workplace well-being: The role of job crafting and autonomy support. Psychology of Well-being, 5(1), 7.

Slemp, G. R., Kern, M. L., Patrick, K. J., \& Ryan, R. M. (2018). Leader autonomy support in the workplace: A meta-analytic review. Motivation and Emotion, 42(5), 706-724.

Slemp, G. R., Zhao, Y., Hou, H., \& Vallerand, R. J. (2020b). Job crafting, leader autonomy support, and passion for work: Testing a model in Australia and China. Motivation and Emotion, 1-15.

* Smith, J. L., Handley, I. M., Rushing, S., Belou, R., Shanahan, E. A., Skewes, M. C., ... \& Intemann, K. (2018). Added benefits: How supporting women faculty in STEM improves everyone's job satisfaction. Journal of Diversity in Higher Education, 11(4), 502-517.

* Stenling, A., \& Tafvelin, S. (2016). Transfer of training after an organizational intervention in Swedish sports clubs: A self-determination theory perspective. Journal of Sport and Exercise Psychology, 38(5), 493-504.

Su, Y. L., \& Reeve, J. (2011). A meta-analysis of the effectiveness of intervention programs designed to support autonomy. Educational Psychology Review, 23(1), 159-188.

* Tafvelin, S., von Thiele Schwarz, U., \& Stenling, A. (2019). Leadership training to increase need satisfaction at work: A quasi-experimental mixed method study. Frontiers in Psychology, 10, 2175 .

Van den Broeck, A., Ferris, D. L., Chang, C. H., \& Rosen, C. C. (2016). A review of selfdetermination theory's basic psychological needs at work. Journal of Management, 42(5), 11951229 .

Van den Broeck, A., Vansteenkiste, M., De Witte, H., \& Lens, W. (2008). Explaining the relationships between job characteristics, burnout, and engagement: The role of basic psychological need satisfaction. Work \& Stress, 22(3), 277-294.

Van den Broeck, A., Vansteenkiste, M., De Witte, H., Soenens, B., \& Lens, W. (2010). Capturing autonomy, competence, and relatedness at work: Construction and initial validation of the Work - related Basic Need Satisfaction scale. Journal of Occupational and Organizational Psychology, 83(4), 981-1002.

Vansteenkiste, M., \& Ryan, R. M. (2013). On psychological growth and vulnerability: Basic psychological need satisfaction and need frustration as a unifying principle. Journal of Psychotherapy Integration, 23(3), 263-280. doi: 10.1037/a0032359 
van Wingerden, J., Bakker, A. B., \& Derks, D. (2017). The longitudinal impact of a job crafting intervention. European Journal of Work and Organizational Psychology, 26(1), 107-119.

* Williams, V., Deane, F. P., Oades, L. G., Crowe, T. P., Ciarrochi, J., \& Andresen, R. (2016). A cluster-randomised controlled trial of values-based training to promote autonomously held recovery values in mental health workers. Implementation Science, 11(1), 13.

* Yong, A., Roche, M., \& Sutton, A. (2019b). Training and maintaining autonomy-supportive supervisory style in low-skilled occupations. Journal of Management \& Organization, 1-19. 
Sample 1

Proximal (e.g., Leaders)

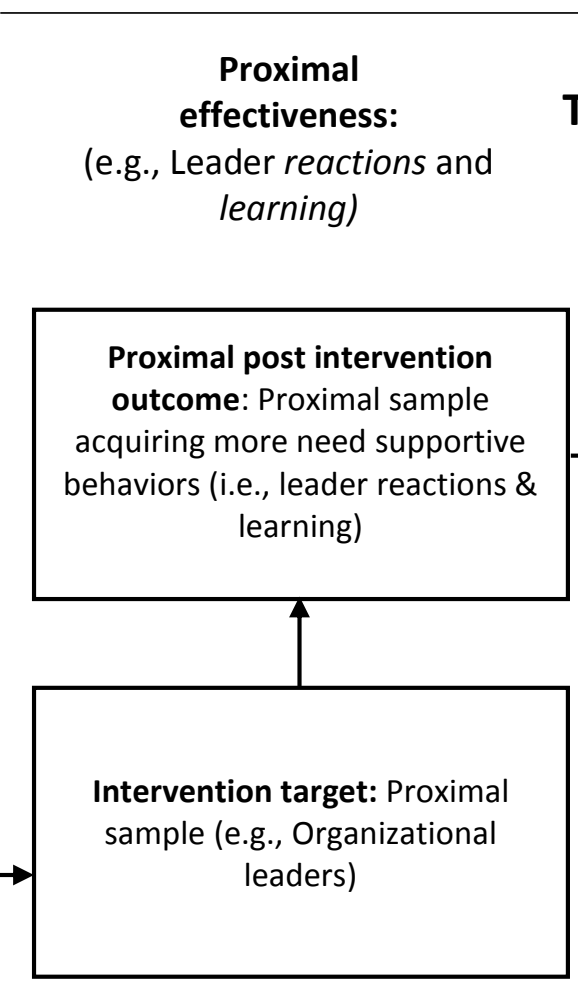

SDT-Informed Need Supportive Intervention
Sample 2

Distal (e.g., Subordinates)

Distal

effectiveness:

(e.g., Subordinate or

organizational results)

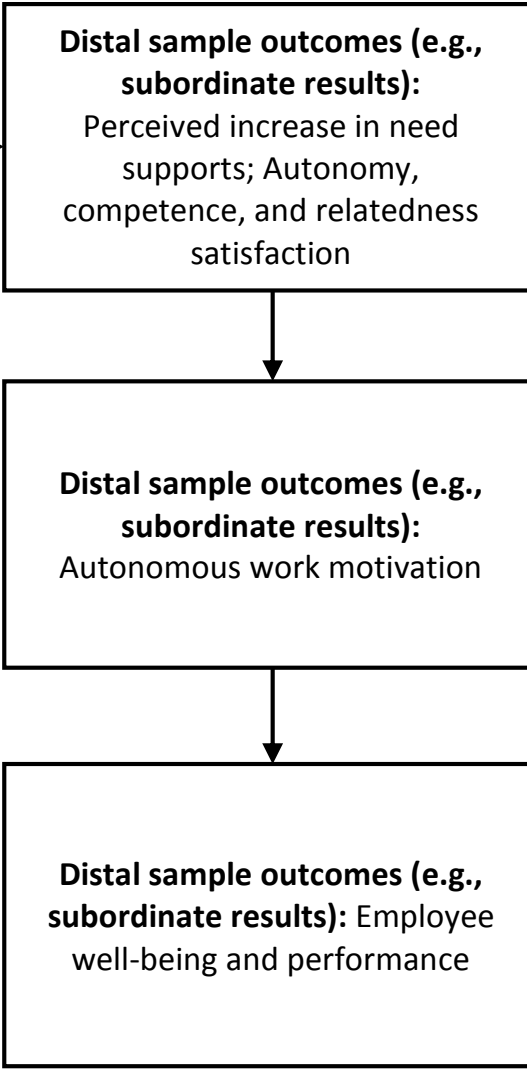

Distal post-

intervention results

Figure 1. Process model showing typical SDT-informed basic need support intervention research process mapped against all Kirkpatrick (1959) outcome criteria to detect proximal and distal effectiveness in organizations 

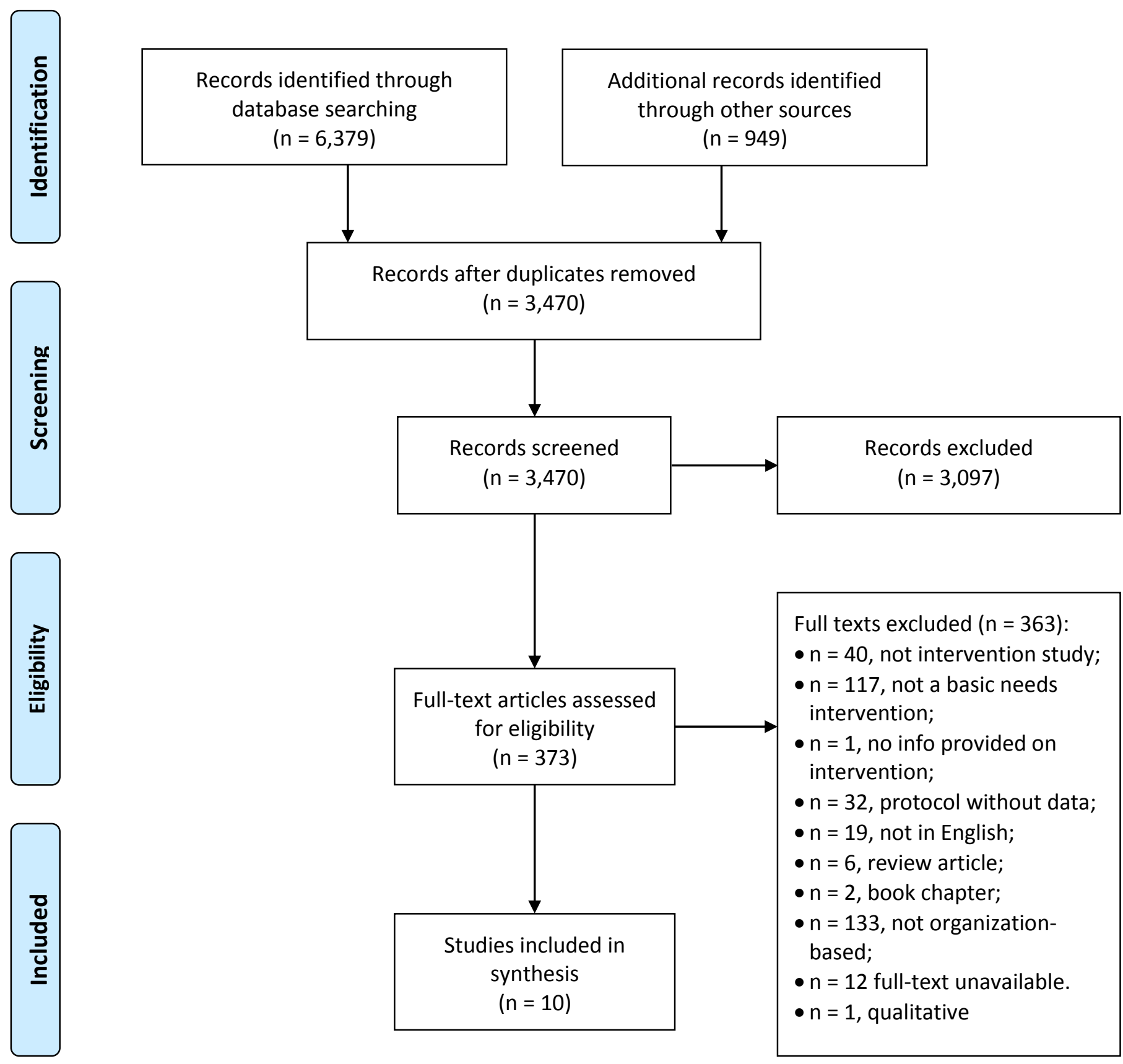

Figure 2. PRISMA flow diagram showing the study screening process. 


\section{Sample 1 \\ Proximal: \\ Leaders/training recipients}

\section{Sample 2 \\ Distal:}

Subordinates/employees

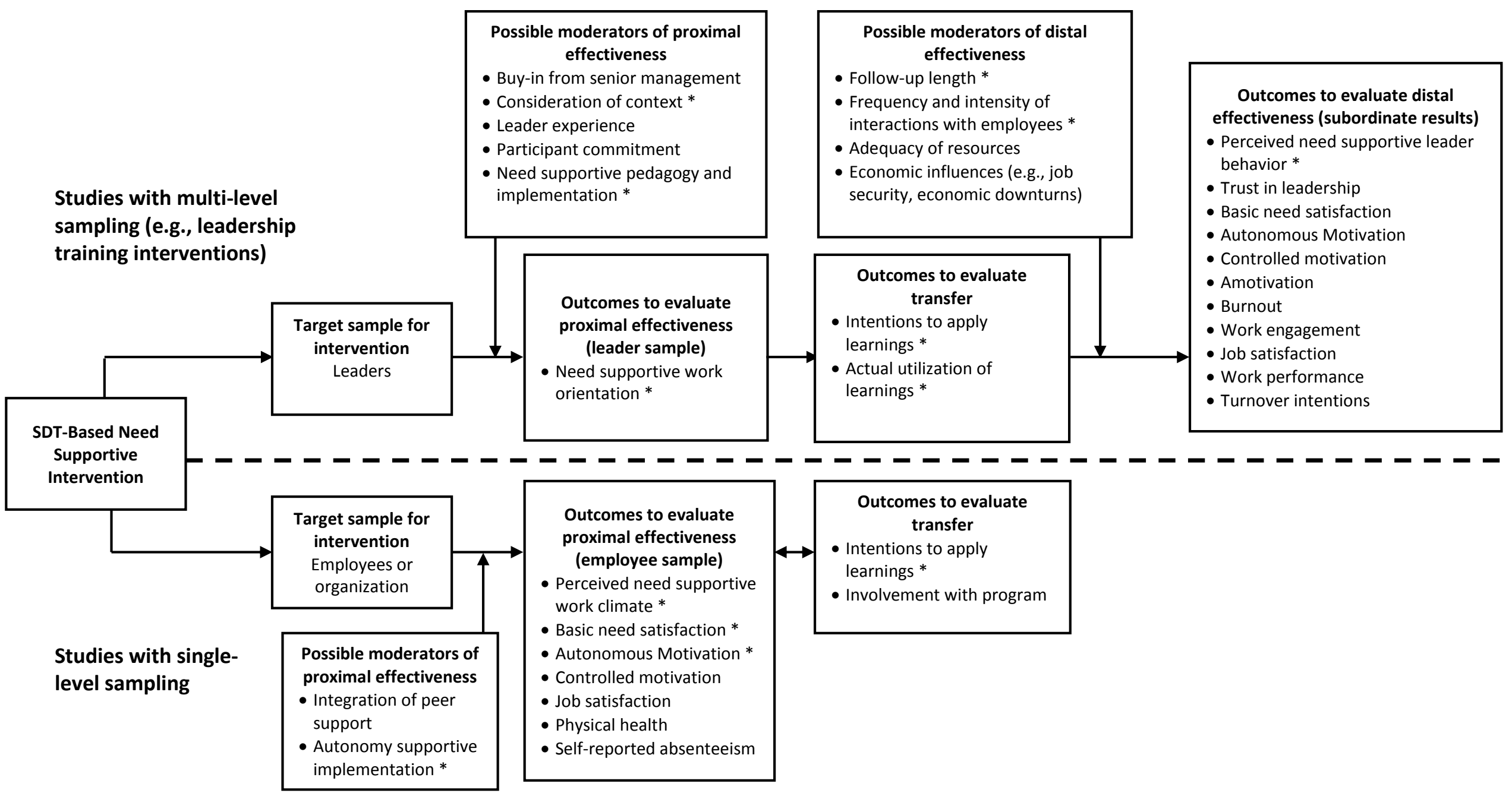

Figure 3. Overview of research examining interventions to support basic psychological needs in organizations. Note: asterisks $(*)$ indicate support for that variable across multiple studies. 
Table 1

Study Codes and Characteristics from the Intervention Studies Included in the Synthesis (1989 to present)

\begin{tabular}{|c|c|c|c|c|c|c|c|c|c|c|}
\hline Study & $\begin{array}{l}\text { Basic Need Supports or } \\
\text { Behaviors Included }\end{array}$ & Design & $\begin{array}{c}\text { Focus, sample } \\
\text { composition, \& } \\
\text { context }\end{array}$ & $N_{T}$ & $N_{C}$ & $N_{S S}$ & Duration & $\begin{array}{c}\text { Follow } \\
\text {-up } \\
\text { (month } \\
\text { s) } \\
\end{array}$ & Primary DVs & Findings \\
\hline $\begin{array}{l}\text { Deci et al. } \\
1989\end{array}$ & $\begin{array}{c}\text { Maximizing } \\
\text { opportunities for } \\
\text { initiative-taking; Positive } \\
\text { informational feedback; } \\
\text { Acceptance of employee } \\
\text { needs and feelings }\end{array}$ & $\begin{array}{c}\text { Quasi } \\
\text { Experimental } \\
\text { Trial }\end{array}$ & $\begin{array}{c}\text { Focus: Leadership } \\
\text { training } \\
\text { Composition: } \\
\text { Multi-level } \\
\text { sampling (leaders } \\
\text { and their teams) } \\
\text { Context: } \\
\text { Technicians/ } \\
\text { general corporate }\end{array}$ & $\begin{array}{c}23 \\
\text { Managers } \\
235 \\
\text { Employees }\end{array}$ & $\begin{array}{c}\text { No Managers } \\
277 \text { Employees } \\
\text { (matched } \\
\text { comparison group) }\end{array}$ & -- & $\begin{array}{l}\text { Preliminary } \\
\text { meetings } \\
\text { plus 2-days } \\
\text { training, with } \\
\text { one-on-one } \\
\text { consultations }\end{array}$ & $\begin{array}{l}\text { Up to } \\
1 \text {-year }\end{array}$ & $\begin{array}{l}\text { Leaders: Autonomy } \\
\text { support orientation } \\
\text { Employees: Work } \\
\text { climate and perceived } \\
\text { autonomy support } \\
\text { Global satisfaction \& } \\
\text { attitudes }\end{array}$ & $\begin{array}{c}\text { Pre-post } \\
\text { improvements in } \\
\text { manager } \\
\text { orientations to be } \\
\text { autonomy } \\
\text { supportive; } \\
\text { Pre-post } \\
\text { improvements in } \\
\text { employee } \\
\text { perceptions of } \\
\text { work climate } \\
\text { (autonomy } \\
\text { support), and } \\
\text { global satisfaction }\end{array}$ \\
\hline $\begin{array}{l}\text { Forner, } \\
2019\end{array}$ & $\begin{array}{l}\text { Focused on developing } \\
\text { autonomy, competence, } \\
\text { and relatedness } \\
\text { supportive behaviors; } \\
\text { specific example } \\
\text { behaviors not provided. } \\
\text { Also incorporated } \\
\text { general behavior change } \\
\text { management training, } \\
\text { roll plays, and } \\
\text { discussions. }\end{array}$ & $\begin{array}{c}\text { Quasi } \\
\text { Experimental } \\
\text { Trial }\end{array}$ & $\begin{array}{l}\text { Focus: Leadership } \\
\text { training } \\
\text { Composition: } \\
\text { Multi-level } \\
\text { sampling (leaders } \\
\text { and their } \\
\text { employees) } \\
\text { Context: Volunteer } \\
\text { emergency services } \\
\text { organization }\end{array}$ & $\begin{array}{c}65 \\
\text { Managers } \\
113 \\
\text { Employees }\end{array}$ & 102 leaders & -- & $\begin{array}{c}2 \text { days, } \\
\text { mentoring } \\
\text { and modules. }\end{array}$ & 1-year & $\begin{array}{l}\text { Leaders: Autonomy } \\
\text { support orientation; } \\
\text { Effort to apply } \\
\text { intervention } \\
\text { Employees: } \\
\text { Perceived autonomy } \\
\text { support; Autonomy, } \\
\text { competence, and } \\
\text { relatedness } \\
\text { satisfactions, job } \\
\text { satisfaction, \& intent } \\
\text { to turnover. }\end{array}$ & $\begin{array}{c}\text { Pre-post } \\
\text { improvements in } \\
\text { manager } \\
\text { orientations to be } \\
\text { autonomy } \\
\text { supportive which } \\
\text { was sustained after } \\
1 \text { year. Effects } \\
\text { moderated by } \\
\text { experience. No } \\
\text { changes observed } \\
\text { in employees over } \\
\text { 9-week duration of } \\
\text { intervention }\end{array}$ \\
\hline
\end{tabular}




\begin{tabular}{|c|c|c|c|c|c|c|c|c|c|c|}
\hline Study & $\begin{array}{l}\text { Basic Need Supports or } \\
\text { Behaviors Included }\end{array}$ & Design & $\begin{array}{c}\text { Focus, sample } \\
\text { composition, \& } \\
\text { context }\end{array}$ & $N_{T}$ & $N_{C}$ & $N_{S S}$ & Duration & $\begin{array}{c}\text { Follow } \\
\text {-up } \\
\text { (month } \\
\text { s) } \\
\end{array}$ & Primary DVs & Findings \\
\hline $\begin{array}{l}\text { Hardré \& } \\
\text { Reeve, } \\
2009\end{array}$ & $\begin{array}{c}\text { Nurturing inner- } \\
\text { motivational resources; } \\
\text { Using informational } \\
\text { (non-controlling) } \\
\text { language; Providing } \\
\text { rationales for requests; } \\
\text { Acceptance of employee } \\
\text { feelings }\end{array}$ & $\mathrm{RCT}$ & $\begin{array}{l}\text { Focus: Leadership } \\
\text { training } \\
\text { Composition: } \\
\text { multi-level } \\
\text { sampling (leaders } \\
\text { and their } \\
\text { employees) } \\
\text { Context: general } \\
\text { corporate }\end{array}$ & $\begin{array}{c}10 \\
\text { Managers } \\
53 \\
\text { Employees }\end{array}$ & $\begin{array}{c}10 \text { Managers } \\
45 \text { Employees } \\
\text { (waitlist control) }\end{array}$ & -- & $\begin{array}{c}2 \times 1 \text {-hour } \\
\text { sessions plus } \\
\text { one-on-one } \\
\text { consultations }\end{array}$ & $\begin{array}{l}\text { No } \\
\text { follow- } \\
\text { up }\end{array}$ & $\begin{array}{l}\text { Leaders: Overall } \\
\text { autonomy support } \\
\text { Employees: Degrees } \\
\text { of self-determined } \\
\text { motivation; } \\
\text { Amotivation; Work } \\
\text { engagement }\end{array}$ & $\begin{array}{c}\text { Large pre-post } \\
\text { improvements in } \\
\text { manager-reported } \\
\text { autonomy support } \\
\text { (Cohen's } d \text { range: } \\
0.71 \text { to } 2.13 \text { ) } \\
\text { Small pre-post } \\
\text { improvements in } \\
\text { types of self- } \\
\text { determined } \\
\text { motivation, and } \\
\text { work engagement } \\
\text { (Cohen's } d \text { range: } \\
0.18 \text { to } 0.44 \text { ) }\end{array}$ \\
\hline $\begin{array}{l}\text { Jungert et } \\
\text { al. } 2018\end{array}$ & $\begin{array}{l}\text { Perspective taking, } \\
\text { communication, and } \\
\text { collaboration to foster } \\
\text { employee basic } \\
\text { psychological needs and } \\
\text { autonomous work } \\
\text { motivation }\end{array}$ & $\begin{array}{c}\text { Quasi } \\
\text { Experimental } \\
\text { Trial }\end{array}$ & $\begin{array}{c}\text { Focus: team } \\
\text { training } \\
\text { Composition: } \\
\text { single-level } \\
\text { sampling (work } \\
\text { teams) } \\
\text { Context: banking } \\
\text { and property }\end{array}$ & $\begin{array}{c}112 \\
\text { (nested in } \\
26 \text { teams) }\end{array}$ & $\begin{array}{c}34 \text { (nested in } 7 \\
\text { teams) }\end{array}$ & -- & $2 \mathrm{x}$ half days & $\begin{array}{l}\text { No } \\
\text { follow- } \\
\text { up }\end{array}$ & $\begin{array}{c}\text { Autonomy, } \\
\text { competence, } \\
\text { relatedness } \\
\text { satisfactions; } \\
\text { Autonomous and } \\
\text { controlled motivation }\end{array}$ & $\begin{array}{c}\text { Significant pre- } \\
\text { post differences in } \\
\text { change favoring } \\
\text { treatment over } \\
\text { control group on } \\
\text { need satisfaction } \\
\text { and autonomous } \\
\text { motivation; Not } \\
\text { significant for } \\
\text { controlled } \\
\text { motivation }\end{array}$ \\
\hline $\begin{array}{l}\text { Pedersen } \\
\text { et al. } \\
2018 ; \\
\text { Pedersen } \\
\text { et al. } 2019 \\
* \text { a }\end{array}$ & $\begin{array}{l}\text { Providing autonomy } \\
\text { support; Structure; } \\
\text { Interpersonal } \\
\text { involvement; Also } \\
\text { focused on developing } \\
\text { need supportive } \\
\text { behaviors within the } \\
\text { HCCQ }\end{array}$ & $\begin{array}{l}\text { Clustered } \\
\text { RCT }\end{array}$ & $\begin{array}{l}\text { Focus: employee / } \\
\text { peer intervention } \\
\text { Composition: } \\
\text { single-level } \\
\text { sampling, } \\
\text { employees within } 6 \\
\text { clusters } \\
\text { Context: transport } \\
\text { and distribution }\end{array}$ & 113 & 89 & -- & $\begin{array}{l}\text { Facilitators, } \\
\text { 8- hours; } \\
\text { employees } \\
7.5 \text { hours } \\
\text { plus peer } \\
\text { support }\end{array}$ & $\begin{array}{l}\text { No } \\
\text { follow- } \\
\text { up }\end{array}$ & $\begin{array}{l}\text { Cardiorespiratory } \\
\text { fitness; Physical } \\
\text { activity; Waist } \\
\text { circumference; Non- } \\
\text { HDL-C (mmol/L); } \\
\text { HDL-C (mmol/L); } \\
\text { Systolic and diastolic } \\
\text { blood pressure; Need } \\
\text { support for physical } \\
\text { activity; Competence } \\
\text { satisfaction; }\end{array}$ & $\begin{array}{c}\text { Significant pre- } \\
\text { post differences in } \\
\text { change favoring } \\
\text { treatment over } \\
\text { control group on } \\
\text { Cardiorespiratory } \\
\text { fitness, HDL-C, } \\
\text { diastolic blood } \\
\text { pressure, need } \\
\text { support for } \\
\text { physical activity; }\end{array}$ \\
\hline
\end{tabular}




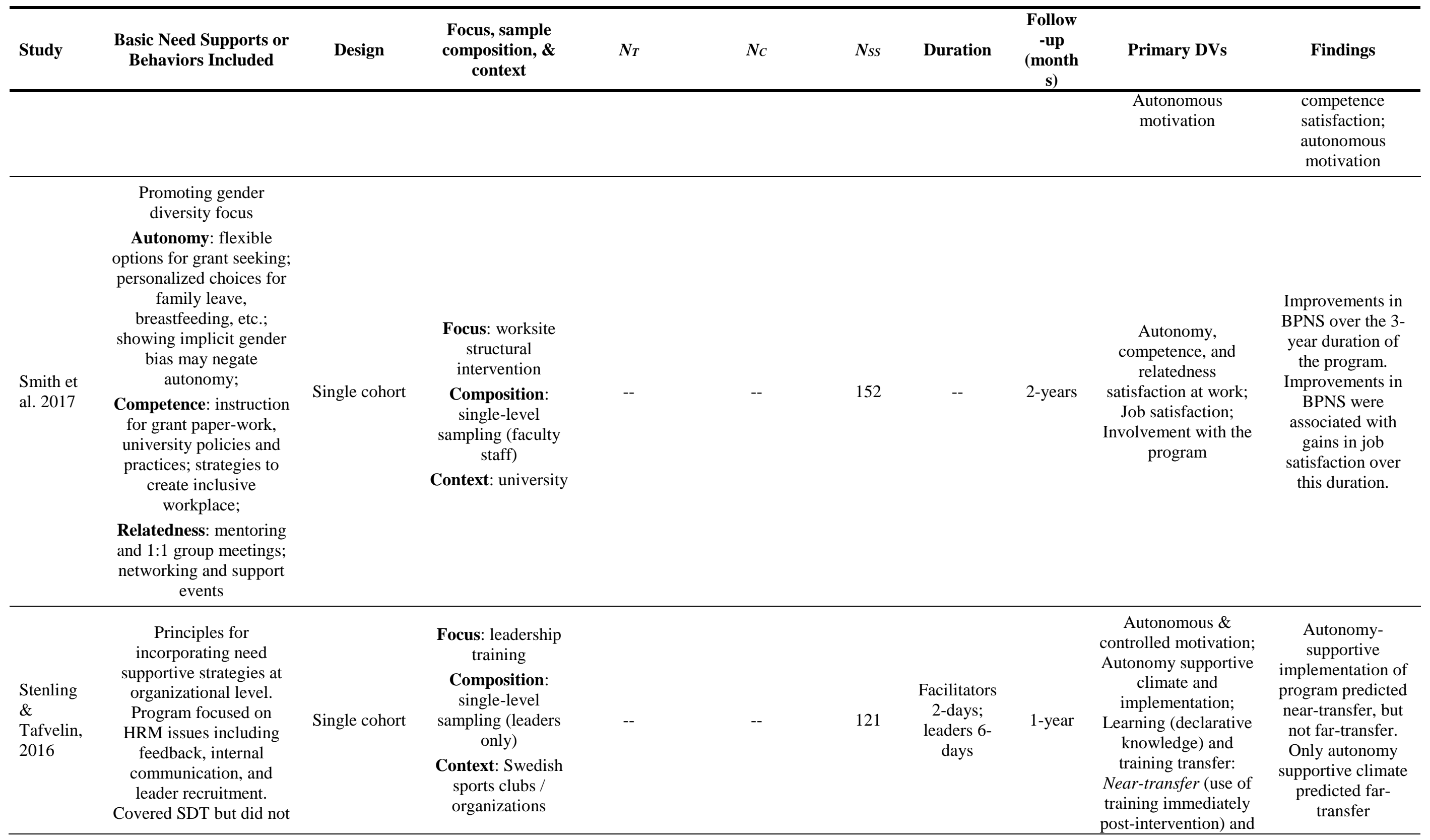




\begin{tabular}{|c|c|c|c|c|c|c|c|c|c|c|}
\hline Study & $\begin{array}{l}\text { Basic Need Supports or } \\
\text { Behaviors Included }\end{array}$ & Design & $\begin{array}{l}\text { Focus, sample } \\
\text { composition, \& } \\
\text { context }\end{array}$ & $N_{T}$ & $N_{C}$ & $N_{S S}$ & Duration & $\begin{array}{c}\text { Follow } \\
\text {-up } \\
\text { (month } \\
\text { s) } \\
\end{array}$ & Primary DVs & Findings \\
\hline & $\begin{array}{l}\text { state which specific } \\
\text { strategies taught. }\end{array}$ & & & & & & & & $\begin{array}{l}\text { far-transfer (use of } \\
\text { training 1-year post- } \\
\text { intervention) }\end{array}$ & \\
\hline $\begin{array}{l}\text { Tafvelin } \\
\text { et al. } 2019\end{array}$ & $\begin{array}{l}\text { Training delivered in } \\
\text { three-parts covering } \\
\text { generic leadership skills } \\
\text { and need-supportive } \\
\text { behaviors (specific } \\
\text { strategies unstated). } \\
\text { Leaders were provided } \\
\text { with 180-degree } \\
\text { feedback and support to } \\
\text { develop a need- } \\
\text { supportive style }\end{array}$ & $\begin{array}{l}\text { Clustered, } \\
\text { Quasi } \\
\text { Experimental } \\
\text { Trial; Mixed } \\
\text { Methods }\end{array}$ & $\begin{array}{c}\text { Focus: leadership } \\
\text { training } \\
\text { Composition: } \\
\text { multi-level (leaders } \\
\text { and their } \\
\text { employees) } \\
\text { Context: Local } \\
\text { government / } \\
\text { municipality }\end{array}$ & $\begin{array}{c}20 \\
\text { managers } \\
202 \\
\text { employees }\end{array}$ & $\begin{array}{l}17 \text { managers } \\
130 \text { employees }\end{array}$ & -- & $\begin{array}{l}2 \times 2 \text {-day } \\
\text { sessions; half } \\
\text { day } \\
\text { follow-up } \\
\text { session }\end{array}$ & $\begin{array}{l}\text { 2- } \\
\text { months }\end{array}$ & $\begin{array}{l}\text { Leaders: autonomy, } \\
\text { competence, } \\
\text { relatedness support; } \\
\text { Employees: } \\
\text { Competence and } \\
\text { relatedness support; } \\
\text { autonomy, } \\
\text { competence, and } \\
\text { relatedness } \\
\text { satisfaction; job } \\
\text { satisfaction; vigor and } \\
\text { dedication; work } \\
\text { performance }\end{array}$ & $\begin{array}{l}\text { No changes } \\
\text { observed in basic } \\
\text { need supports; } \\
\text { larger decline in } \\
\text { competence and } \\
\text { relatedness } \\
\text { satisfactions for } \\
\text { control group; } \\
\text { vigor declined in } \\
\text { the treatment } \\
\text { group but not } \\
\text { control group. }\end{array}$ \\
\hline $\begin{array}{l}\text { Williams } \\
\text { et al. } 2016\end{array}$ & $\begin{array}{l}\text { Training centered on the } \\
\text { autonomous } \\
\text { identification and } \\
\text { integration of values with } \\
\text { the context of the } \\
\text { collaborative recovery } \\
\text { model (Crowe et al., } \\
\text { 2006) as the format of } \\
\text { autonomy supportive } \\
\text { training. Aimed to } \\
\text { increase integrated } \\
\text { regulation. }\end{array}$ & $\begin{array}{l}\text { Clustered } \\
\text { RCT }\end{array}$ & $\begin{array}{c}\text { Focus: Employee } \\
\text { training } \\
\text { Composition: } \\
\text { single-level } \\
\text { sampling (mental } \\
\text { health workers) } \\
\text { Context: } \\
\text { Community } \\
\text { managed } \\
\text { organizations }\end{array}$ & $\begin{array}{c}70 \\
\text { workers }\end{array}$ & 60 workers & -- & 3-days & $\begin{array}{l}\text { No } \\
\text { follow- } \\
\text { up }\end{array}$ & $\begin{array}{l}\text { Autonomous and } \\
\text { controlled motivation; } \\
\text { Plans to implement } \\
\text { training }\end{array}$ & $\begin{array}{l}\text { Significant pre- } \\
\text { post differences in } \\
\text { change favoring } \\
\text { treatment over } \\
\text { control group on } \\
\text { integrated } \\
\text { motivation and } \\
\text { plans to implement } \\
\text { training; No } \\
\text { significant } \\
\text { differences } \\
\text { observed for } \\
\text { intrinsic, } \\
\text { introjected, or } \\
\text { external regulation }\end{array}$ \\
\hline $\begin{array}{l}\text { Yong et } \\
\text { al. } 2019 b\end{array}$ & $\begin{array}{l}\text { Providing rationale } \\
\text { behind each task; } \\
\text { acknowledging } \\
\text { employees negative }\end{array}$ & $\begin{array}{c}\text { Quasi } \\
\text { Experimental } \\
\text { Trial; Mixed } \\
\text { Methods }\end{array}$ & $\begin{array}{l}\text { Focus: Leadership } \\
\text { training } \\
\text { Composition: } \\
\text { multi-level (leaders }\end{array}$ & $\begin{array}{c}16 \\
\text { supervisor } \\
\mathrm{s}\end{array}$ & $\begin{array}{l}28 \text { supervisors } \\
136 \text { employees }\end{array}$ & -- & $\begin{array}{l}2 \times 1.5 \text {-hour } \\
\text { sessions; } 1- \\
\text { hour follow- } \\
\text { up session }\end{array}$ & $\begin{array}{l}\text { 3- } \\
\text { months } \\
\text { s }\end{array}$ & $\begin{array}{l}\text { Leaders: Autonomy } \\
\text { support orientation } \\
\text { Employees: } \\
\text { Perceived autonomy }\end{array}$ & $\begin{array}{l}\text { Managers showed } \\
\text { increase in } \\
\text { autonomy support } \\
\text { post-intervention }\end{array}$ \\
\hline
\end{tabular}




\begin{tabular}{|c|c|c|c|c|c|c|c|c|c|c|}
\hline Study & $\begin{array}{l}\text { Basic Need Supports or } \\
\text { Behaviors Included }\end{array}$ & Design & $\begin{array}{c}\text { Focus, sample } \\
\text { composition, \& } \\
\text { context }\end{array}$ & $N_{T}$ & $N_{C}$ & $N_{S S}$ & Duration & $\begin{array}{l}\text { Follow } \\
\text {-up } \\
\text { (month } \\
\text { s) }\end{array}$ & Primary DVs & Findings \\
\hline & $\begin{array}{c}\text { feelings; Using } \\
\text { informational (non- } \\
\text { controlling) language } \\
\text { and feedback; nurturing } \\
\text { inner motivational } \\
\text { resources by fostering } \\
\text { ownership over tasks, } \\
\text { creating opportunities for } \\
\text { choice, creating adequate } \\
\text { level of challenge }\end{array}$ & & $\begin{array}{c}\text { and their } \\
\text { employees) } \\
\text { Context: "low- } \\
\text { skilled occupations" } \\
\text { in factory and hotel } \\
\text { settings }\end{array}$ & $\begin{array}{c}104 \\
\text { employees }\end{array}$ & & & & & $\begin{array}{l}\text { support; Autonomy, } \\
\text { competence, and } \\
\text { relatedness } \\
\text { satisfaction and } \\
\text { frustration }\end{array}$ & $\begin{array}{c}\text { for treatment } \\
\text { group, but not } \\
\text { controls. Few other } \\
\text { differences } \\
\text { emerged for } \\
\text { between treatment } \\
\text { and control for } \\
\text { managers or } \\
\text { employees }\end{array}$ \\
\hline
\end{tabular}

Note: $N_{T}$ : sample size for treatment group; $N_{C}$ : sample size for control group; $N_{S S}$ : sample size for single-cohort studies; Sample sizes shown for posttreatment and after attrition. BPNS = basic psychological need satisfaction; HCCQ = Health Care Climate Questionnaire; ITT = intent to treat; * ITT sample size and effects used. RCT $=$ randomized-controlled trial; ${ }^{\text {a }}$ Pedersen et al. 2018 and Pedersen et al. 2019 appear on the same row and appear as one study because both publications are based on the same sample. 


\section{Supplemental materials (SM) for}

Interventions to Support Autonomy, Competence, and Relatedness Needs in Organizations: A Systematic Review

\section{Section A:}

Search term word sets used to run the systematic search:

- Set 1: "autonom* support" or "support for autonomy" or "needs support" or "need support" or "competence support" or "support for competence" or "relatedness support" or "support for relatedness")

- Set 2: Training or Program* or Intervention* or pilot or trial or feasibil* or evaluat* 


\section{Section B:}

Risk of Bias Assessments Across the Studies Included in the Review

\begin{tabular}{|c|c|c|c|c|c|c|c|}
\hline Study & Selection Bias & Study Design & Confounders & Blinding & $\begin{array}{c}\text { Data } \\
\text { Collection } \\
\text { Methods }\end{array}$ & $\begin{array}{l}\text { Withdrawals } \\
\text { and Dropouts }\end{array}$ & Risk of Bias \\
\hline Deci et al. 1989 & $2=$ moderate & $1=$ strong & 3 = weak & $3=$ weak & $1=$ strong & $3=$ weak & High \\
\hline Forner, 2019 & $2=$ moderate & $1=$ strong & $1=$ strong & $3=$ weak & $1=$ strong & $2=$ moderate & Moderate \\
\hline Hardré \& Reeve, 2009 & $1=$ strong & $1=$ strong & $3=$ weak & $3=$ weak & $2=$ moderate & $3=$ weak & High \\
\hline Jungert et al. 2018 & $1=$ strong & $1=$ strong & $2=$ moderate & $3=$ weak & $1=$ strong & $2=$ moderate & Moderate \\
\hline Pedersen et al. 2018, 2019 & $1=$ strong & $1=$ strong & $1=$ strong & $3=$ weak & $1=$ strong & $1=$ strong & Moderate \\
\hline Smith et al. 2017 & $2=$ moderate & $2=$ moderate & $3=$ weak & $3=$ weak & $1=$ strong & $3=$ weak & High \\
\hline Stenling \& Tafvelin, 2016 & $1=$ strong & $2=$ moderate & $3=$ weak & $3=$ weak & $1=$ strong & $3=$ weak & High \\
\hline Tafvelin et al. 2019 & $2=$ moderate & $1=$ strong & $1=$ strong & $3=$ weak & $3=$ weak & $2=$ moderate & High \\
\hline Williams et al. 2016 & $2=$ moderate & $1=$ strong & $1=$ strong & $3=$ weak & $1=$ strong & $1=$ strong & Moderate \\
\hline Yong et al. 2019b & $2=$ moderate & $1=$ strong & $3=$ weak & $3=$ weak & $2=$ moderate & $3=$ weak & High \\
\hline
\end{tabular}




\section{University Library}

\section{- M I I N E R VA \\ A gateway to Melbourne's research publications}

Minerva Access is the Institutional Repository of The University of Melbourne

Author/s:

Slemp, G;Lee, MA;Mossman, LH

Title:

Interventions to support autonomy, competence, and relatedness needs in organizations: A systematic review with recommendations for research and practice

Date:

2021-06-01

\section{Citation:}

Slemp, G., Lee, M. A. \& Mossman, L. H. (2021). Interventions to support autonomy, competence, and relatedness needs in organizations: A systematic review with recommendations for research and practice. Journal of Occupational and Organizational Psychology, 94 (2), pp.427-457. https://doi.org/10.1111/joop.12338.

Persistent Link:

http://hdl.handle.net/11343/260494 